\title{
A Phytochrome Sensory Domain Permits Receptor Activation by Red Light
}

\author{
Eva Reichhart, Alvaro Ingles-Prieto, Alexandra-Madelaine Tichy, Catherine McKenzie and Harald \\ Janovjak $^{*[a]}$
}

\begin{abstract}
Optogenetics and photopharmacology enable the spatiotemporal control of cell and animal behavior by light. Red light offers deep tissue penetration and minimal phototoxicity, but very few red light-sensitive optogenetic methods are currently available. Here, we developed a red light-induced homodimerization domain. We first showed that an optimized sensory domain of the cyanobacterial phytochrome 1 (CPH1) can be expressed robustly and without cytotoxicity in human cells. We then applied this domain to induce dimerization of two receptor tyrosine kinases, the fibroblast growth factor receptor 1 and the neurotrophin receptor trkB. With this new optogenetic method in hand, we activated the MAPK/ERK pathway non-invasively in mammalian tissue and developed multi-color cell signaling experiments. The light-controlled dimerizer and the red light-activated receptor tyrosine kinases will prove useful to regulate a variety of cellular processes with light.
\end{abstract}

Optogenetics has revolutionized neuroscience and cell biology by providing optical, thus spatially and temporally precise, means to decode molecular and cellular networks. Light regulation of protein function is often achieved through genetically engineered intra- or intermolecular (un-)binding reactions ${ }^{[1]}$ For instance, in the light-activated GTPase Rac1 ${ }^{[2]}$, a C-terminal helix dissociates from its light-oxygen-voltage sensing (LOV) domain core to release inhibition of enzyme function. In light-activated gene regulation and membrane recruitment, LOV domains either homodimerize or cryptochromes heterodimerize with interacting factors in functionally relevant complexes. ${ }^{[3]}$ In these photoreceptors, flavin cofactors (flavin mononucleotide or flavin adenine dinucleotide) endowing sensitivity to blue light (Figure 1a). However, blue light overlaps with wavelengths used for imaging of many fluorophores and exhibits limited tissue penetration. Application of red light can overcome these limitations but is restricted to reactions of cyclic (di)nucleotides or heterodimerization. ${ }^{[4]}$ Here, we extended the arsenal of light-controlled reactions with a red light-sensing homodimerizer, which we repurposed from the cyanobacterial phytochrome 1 (CPH1) of Synechocystis and applied to activate membrane receptors orthogonally from fluorescent proteins and in mammalian tissue.

[a] E. Reichhart, Dr. A. Ingles-Prieto, A.-M. Tichy, C. McKenzie, Dr. H. Janovjak

Synthetic Physiology

Institute of Science and Technology Austria (IST Austria)

Am Campus 1, 3400 Klosterneuburg (Austria)

E-mail: harald@ist.ac.at

Supporting information for this article is given via a link at the end of the document.
Phytochromes form a diverse protein family in microbes and plants that senses light through bound linear tetrapyrroles (Figure 1a) ${ }^{[5]}$ In particular, some phytochromes, including CPH1, are converted between red light-absorbing $\mathrm{Pr}$ states and far red light-absorbing Pfr states. In vitro, the sensory module of $\mathrm{CPH} 1$ (CPH1S; Figure 1b), which corresponds to the C-terminally truncated protein, was shown to undergo light-dependent changes in oligomerization state. ${ }^{[6]}$ Red light resulted in the homodimeric Pfr state and far red light in the monomeric Pr state (Figure 1c). We hypothesized that this domain may be developed into a new tool to control protein-protein interactions by red light in mammalian cells. Because CPH1S was not expressed in mammalian cells previously, we tested if its biogenesis is harmonious with mammalian protein production in human embryonic kidney 293 (HEK293) cells. We first fused a 1539 basepair-fragment ( $\mathrm{CPH} 1 \mathrm{~S})$ from genomic DNA to the bright yellow fluorescent protein mVenus, which allowed for quantification of $\mathrm{CPH} 1 \mathrm{~S}$ expression in the context of a fusion protein. We observed weak fluorescence in HEK293 cells transfected with mVenus-CPH1S (Figure 1d), indicative of poor protein expression that may impede its straight-forward use. We reasoned that limited expression might originate from divergent codon usage of the cyanobacterial gene and mammalian host cells. ${ }^{[7]}$ Indeed, a synthetic codon-optimized variant of the gene (CPH1S-o) showed increased expression without measurable cytotoxicity (Figure 1d and e).

Homodimerization underlies the function of diverse protein families, such as kinases, cadherins, antibodies, motor proteins and transcription factors. For instance, for many receptor tyrosine kinases (RTKs) previously it was shown that homodimerization is required and can be sufficient for initiation of downstream signaling pathways, such as mitogen-activated protein kinases/extracellular signal-regulated kinase (MAPK/ERK) or phosphatidylinositol-3 kinase/Akt (PI3K/Akt) pathways. ${ }^{[8]}$ To create a red light-activated RTK, we fused $\mathrm{CPH} 1 \mathrm{~S}-\mathrm{O}$ to the far C-terminus of the murine fibroblast growth factor receptor 1 (mFGFR1) (Figure 2a). At this position, chemical homodimerization domains, such as an engineered FK506 binding protein (FKBP), or fluorescent proteins were previously incorporated. ${ }^{[9]}$ The extracellular domain of the receptor was replaced by a myristoylation domain to obtain a receptor that is inert to its natural ligands. ${ }^{[9 a, 10]}$ We next examined the ability of mFGFR1-CPH1S-o to activate the MAPK/ERK pathway in response to red light in HEK293 cells. Cells supplemented with the tetrapyrrole phycocyanobillin (PCB) responded to $\operatorname{dim}$ red light $\left(I=6.2 \mu \mathrm{W} \mathrm{cm}{ }^{-2}, \lambda \approx 630 \pm 5 \mathrm{~nm}\right)$ with strong pathway activation as measured using a transcriptional reporter (Figure $2 \mathrm{~b}$ ). Control experiments showed that (i) blue (I $\left.=150 \mu \mathrm{W} \mathrm{cm} \mathrm{cm}^{-2}, \lambda \approx 470 \pm 5 \mathrm{~nm}\right)$ or green $\left(I=6.2 \mu \mathrm{W} \mathrm{cm}{ }^{-2}, \lambda \approx\right.$ 
$530 \pm 5 \mathrm{~nm}$ ) light did not result in pathway activation, (ii) red light had no effect after loss of kinase activity (Y271F and Y272F mutations) or on a fusion protein of mFGFR1 and FKBP (Figure $2 b)$. Notably, the results obtained on mFGFR1-FKBP indicated absence of receptor dimerization of mFGFR1-CPH1S-o in the dark. Finally, substituting a conserved arginine (R195) in the mFGFR1 catalytic domain with a negative charge, which prevents formation of an essential, asymmetric kinase domain dimer ${ }^{[11]}$, abolished pathway activation, indicating that dimerization is required for receptor activation by CPH1S-o (Figure 2b).
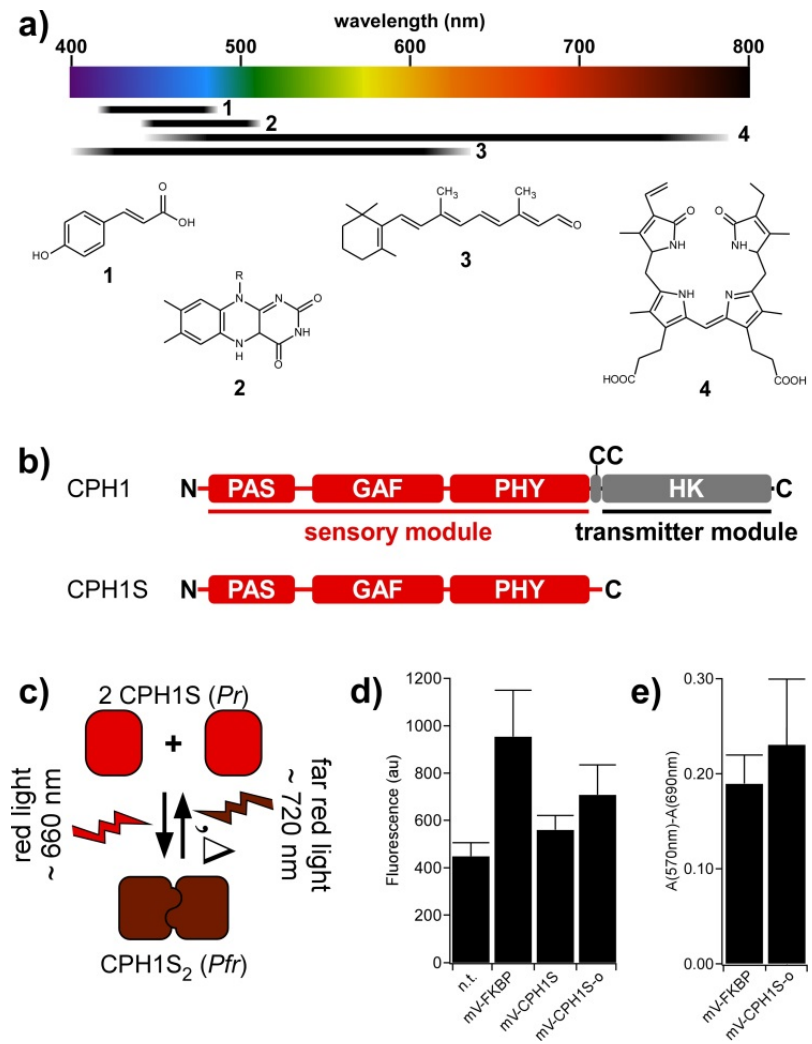

Figure 1. a) Chromophores of main photoreceptor classes (1: p-coumaric acid 2: flavins, 3: retinal, 4: tetrapyrroles). b) Domain structure of $\mathrm{CPH} 1$ with light sensory (CPH1S) and transmitter module (PAS: Per Arnt Sim, GAF: cGMPspecific phosphodiesterase, adenylyl cyclase and FhIA, PHY: phytochrome, HK: histidine kinase). c) $\mathrm{CPH} 1 \mathrm{~S}$ can be interconverted between a mainly monomeric $\mathrm{Pr}$ state and mainly homodimeric $\mathrm{Pfr}$ state. d) Fluorescence intensity for HEK293 cells expressing mVenus (mV)-tagged CPH1S, CPH1S-o and FKBP. n.t.: non-transfected cells. e) Viability of HEK293 cells transfected with $\mathrm{mV}$-FKBP or $\mathrm{mV}$-CPH1S-o. In $\mathrm{d}$ ) and e), mean values $\pm \mathrm{SD}$ for three independent experiments each performed in triplicates are shown.

We extended this design principle to a second RTK, the rat neurotrophin receptor trkB (rtrkB). Also in this case, red light resulted in pathway activation (Figure $2 \mathrm{c}$ ) that depended on $\mathrm{PCB}$ (Figure S1). Immunoblotting demonstrated that activation of the MAPK/ERK and PI3K/Akt pathways returned to basal levels $\approx 30$ min after light illumination (Figure S2). Overall, incorporation of $\mathrm{CPH} 1 \mathrm{~S}-\mathrm{O}$, but not of other cyano- or proteobacterial phytochromes (Figure S3), into RTKs enabled activation of the receptors and key pathways by red light.

Light absorbed by $\mathrm{CPH} 1$ and other phytochromes is redshifted compared to that absorbed by many fluorescent proteins (e.g. typical blue, green and red fluorescent proteins are excited at $\approx 440,490$ and $560 \mathrm{~nm}$, resp.). This property has been taken advantage of in studies that applied phytochromes as spectrallyseparated fluorophores in multi-color imaging ${ }^{[12]}$ Inspired by this work, we explored whether $\mathrm{CPH} 1 \mathrm{~S}-\mathrm{o}$ can be combined with fluorescent proteins (e.g., mCerulean3: $\lambda \mathrm{Ex} / \mathrm{Em}=433 / 475 \mathrm{~nm}$, mCherry: $\lambda \mathrm{Ex} / \mathrm{Em}=587 / 610 \mathrm{~nm}){ }^{[13]}$ The goal of these experiments was optical actuation of cells (CPHS1-o), combined with optical detection of their signaling state (the first fluorescent protein) and viability (the second fluorescent protein) (Figure 2d). We first engineered transcriptional fluorescent reporters of the MAPK/ERK pathway in which mCerulean3 or mCherry were under control of the pathway-sensitive serum response element (SRE). ${ }^{[14]}$ We next tested whether these proteins are indeed spectrally separated from red light used for $\mathrm{CPH} 1 \mathrm{~S}-\mathrm{o}$ activation. As expected, we found that red light did not result in bleaching of these two proteins (Figure S4), and thus the reporters can faithfully detect pathway activation by mFGFR1-CPH1S-o (Figure 2e). Using the three components, we went on to demonstrate that light-induced cell signaling can be detected separately from cell viability in the same experiment. We prepared a viability reporter in which mCerulean3 was under the control of the constitutively active cytomegalovirus (CMV) promoter, and then applied this viability reporter in combination with the mCherry MAPK/ERK pathway reporter. We incubated cells either in a high concentration of DMSO to induce cell death or in the specific MAPK/ERK pathway inhibitor Trametinib (TRA) (Figure $2 \mathrm{~d}$ ). The addition of TRA reduced the red light-induced mCherry signal but not the mCerulean3 signal (Figure 2f). In contrast the addition of DMSO lead to the reduction of both signals (Figure 2f). Thus, taking advantage of spectral separation of $\mathrm{CPH} 1 \mathrm{~S}-\mathrm{o}$, we showed that effects of specific inhibitors can be distinguished from those of unspecific toxins in a single all-optical experiment. In future experiments, different colors of light may be used to independently activate two or more processes in the same cell or two or more cell types in a heterogeneous population to study cross-talk of cellular signaling pathways or cell-cell interactions.

An important trait of red light is its ability to penetrate tissue more deeply than blue and green light. Because experiments with blue light in mouse models often rely on implants or powerful light sources ${ }^{[3 b, 15]}$, we tested if CPH1S-o can be activated directly and transdermally in tissues. Indeed, when illuminating HEK293 cells transfected with rtrkB-CPH1S-o through synthetic muscle, skin and skull (Figure S5), we found potent activation of signaling (Figure S6). Notably, the applied light intensities were easily attained with light emitting diodes and even lower than those used in photodynamic therapy ${ }^{[16]}$ For mouse abdomen (including skin, muscle, fat and spine; thickness $10 \mathrm{~mm}$ ) (Figure S7), we found that the MAPK/ERK pathway was activated by red light in INS-1E cells transfected with mFGFR1-CPH1S-o $\left(I=3.0 \mathrm{~mW} \mathrm{~cm}^{-2}, \lambda \approx 647 \pm 35 \mathrm{~nm}\right)$ (Figure S8). We chose INS-1E cells, an insulinoma model for pancreatic $\beta$-cells ${ }^{[17]}$, for these experiments because $\beta$-cells signaling is regulated by FGFs and because $\beta$-cells are located 
$\approx 10 \mathrm{~mm}$ from the mouse skin. Collectively, these data show activation of cell signaling through mammalian tissues opening avenues to further non-invasive in vivo optogenetic studies. a)

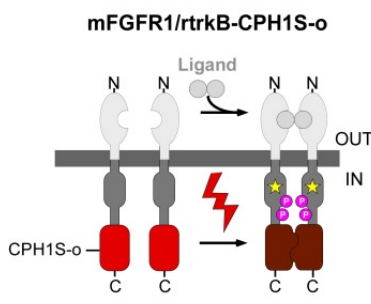

b)

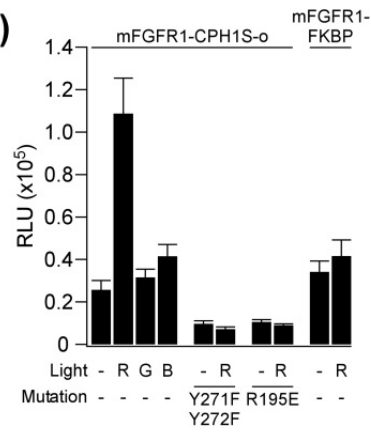

c)

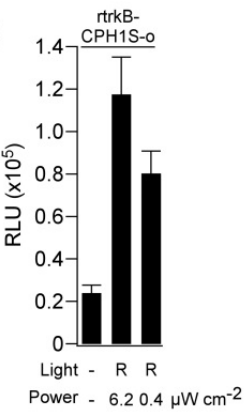

e)

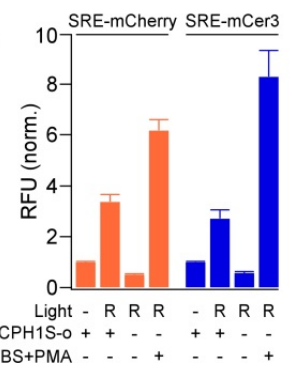

d)
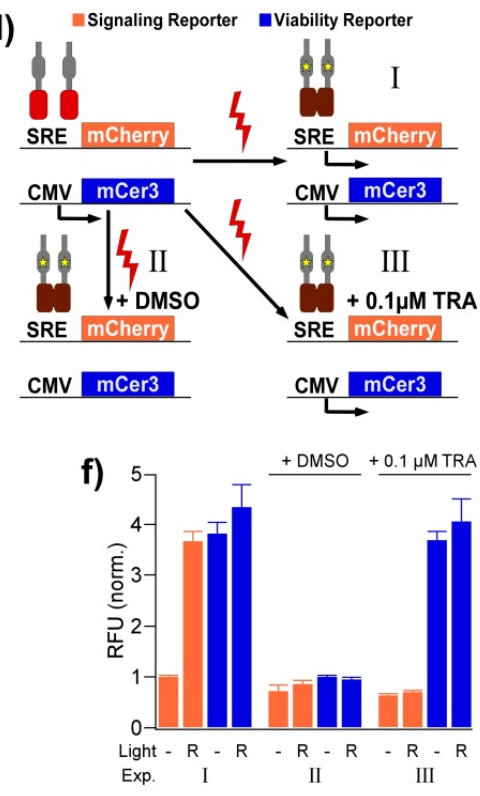

Light-sensitive proteins that undergo reversible inter- or intramolecular binding reactions are the motors of many optogenetic methods. By identifying and adapting the sensory domain of the cyanobacterial phytochrome $\mathrm{CPH} 1$, we introduced an approach for the stoichiometric, red light-induced homodimerization of proteins. Light-induced dimer assembly may be applied to regulate cell adhesion, gene transcription, or the cytoskeleton, potentially also by forming larger complexes after incorporation of multiple photoreceptor domains.

\section{Acknowledgements}

We thank M. Spanova and K. Kolev for technical assistance, R. Riedler, S. Laukoter and S. zur Nedden for help with initial experiments, P. Maechler for INS-1E cells, I. Maldener for cyanobacteria, R.Y. Tsien for mCherry and mVenus, $M$. Davidson for mCerulean3 and M. Grusch for discussions. This work was supported by EU FP7 (CIG-303564). A.I.-P. was supported by a Ramon Areces fellowship, and E.R. by the graduate program MolecularDrugTargets (Austrian Science Fund (FWF): W1232) and a FemTech fellowship (Austrian Research Promotion Agency: 3580812).

Keywords: optogenetics, phytochrome, photochromism, receptors

[1] a) K. Muller, W. Weber, Mol Biosyst. 2013, 9, 596-608; b) A. Moglich, K. Moffat, Photochem Photobiol Sci. 2010, 9, 1286-1300.

[2] Y. I. Wu, D. Frey, O. I. Lungu, A. Jaehrig, I. Schlichting, B. Kuhlman, K M. Hahn, Nature 2009, 461, 104-108.

[3] a) M. J. Kennedy, R. M. Hughes, L. A. Peteya, J. W. Schwartz, M. D. Ehlers, C. L. Tucker, Nat Methods 2010, 7, 973-975; b) X. Wang, X. Chen, Y. Yang, Nat Methods 2012, 9, 266-269.

[4] a) M. H. Ryu, I. H. Kang, M. D. Nelson, T. M. Jensen, A. I. Lyuksyutova, J. Siltberg-Liberles, D. M. Raizen, M. Gomelsky, Proc Natl Acad Sci U S A 2014, 111, 10167-10172; b) C. Gasser, S. Taiber, C. M. Yeh, C. H. Wittig, P. Hegemann, S. Ryu, F. Wunder, A. Moglich, Proc Natl Acad Sci U S A 2014, 111, 8803-8808; c) M. Folcher, S. Oesterle, K. Zwicky, T. Thekkottil, J. Heymoz, M. Hohmann, M. Christen, M. Daoud El-Baba, P. Buchmann, M. Fussenegger, Nat Commun. 2014, 5, 5392; d) A. Levskaya, O. D. Weiner, W. A. Lim, C. A. Voigt, Nature 2009, 461, 9971001.

red light-activated receptors, $b$ and c) MAPK/ERK pathway activation by mFGFR1-CPH1S-o (b) and rtrkB-CPH1S-o (c) in response to red (R), green $(G)$ and blue (B) light. Pathway activation is expressed as reporter gene levels in HEK293 cells. d) Multi-color experiments to test receptor/pathway inhibition and cell viability. (I) CMV-mCerulean3 is expressed constitutively whereas SRE-mCherry depends on MAPK/ERK pathway activation (mCer3: mCerulean3). (II) Addition of DMSO leads to cell death, resulting in neither mCherry nor mCerulean3 expression. (III) Addition of $0.1 \mu \mathrm{M}$ Trametinib (TRA) prevents MAPK/ERK pathway activation whereas viability is not affected. e) MAPK/ERK pathway activation by mFGFR1-CPH1S-o in response to red light measured with SRE-mCherry/-mCerulean3. FBS/PMA was used as positive control. Activation is expressed as mCherry or mCerulean3 levels. f) Experimental realization of d), MAPK/ERK pathway activation in response to red light after treatment with DMSO or TRA. Pathway activation and cell viability is expressed as mCherry and mCerulean3 levels, resp. In b) and c), mean values \pm SEM for two to 17 independent experiments each performed in triplicates are shown. In e) and f), mean values \pm SEM for three independent experiments each performed in triplicates are shown.
[5] N. C. Rockwell, J. C. Lagarias, Chemphyschem. 2010, 11, 1172-1180.

[6] H. M. Strauss, P. Schmieder, J. Hughes, FEBS Lett. 2005, 579, 39703974.

[7] a) K. D. Wells, J. A. Foster, K. Moore, V. G. Pursel, R. J. Wall, Transgenic Res. 1999, 8, 371-381; b) P. M. Sharp, E. Cowe, D. G. Higgins, D. C. Shields, K. H. Wolfe, F. Wright, Nucleic Acids Res. 1988, $16,8207-8211$.

[8] J. Schlessinger, Cell 2000, 103, 211-225.

[9] a) B. E. Welm, K. W. Freeman, M. Chen, A. Contreras, D. M. Spencer, J. M. Rosen, J Cell Biol. 2002, 157, 703-714; b) D. M. Bryant, F. G. Wylie, J. L. Stow, Mol Biol Cell 2005, 16, 14-23.

[10] M. Grusch, K. Schelch, R. Riedler, E. Reichhart, C. Differ, W. Berger, A. Ingles-Prieto, H. Janovjak, EMBO J. 2014, 33, 1713-1726.

[11] J. H. Bae, T. J. Boggon, F. Tome, V. Mandiyan, I. Lax, J. Schlessinger, Proc Natl Acad Sci U S A 2010, 107, 2866-2871.

[12] a) X. Shu, A. Royant, M. Z. Lin, T. A. Aguilera, V. Lev-Ram, P. A. Steinbach, R. Y. Tsien, Science 2009, 324, 804-807; b) D. M. Shcherbakova, V. V. Verkhusha, Nat Methods 2013, 10, 751-754. 
[13] a) M. L. Markwardt, G. J. Kremers, C. A. Kraft, K. Ray, P. J. Cranfill, K. A. Wilson, R. N. Day, R. M. Wachter, M. W. Davidson, M. A. Rizzo, PLoS One 2011, 6, e17896; b) N. C. Shaner, R. E. Campbell, P. A. Steinbach, B. N. Giepmans, A. E. Palmer, R. Y. Tsien, Nat Biotechnol. 2004, 22, 1567-1572.

[14] C. S. Hill, R. Treisman, EMBO J. 1995, 14, 5037-5047.

[15] A. M. Aravanis, L. P. Wang, F. Zhang, L. A. Meltzer, M. Z. Mogri, M. B. Schneider, K. Deisseroth, J Neural Eng 2007, 4, S143-156.

[16] a) J. P. Celli, B. Q. Spring, I. Rizvi, C. L. Evans, K. S. Samkoe, S. Verma, B. W. Pogue, T. Hasan, Chem Rev 2010, 110, 2795-2838; b) B. C. Wilson, M. S. Patterson, Phys Med Biol 2008, 53, R61-109.

[17] A. Merglen, S. Theander, B. Rubi, G. Chaffard, C. B. Wollheim, P. Maechler, Endocrinology 2004, 145, 667-678. 


\section{COMMUNICATION}

Go deep with red: The sensory domain of the cyanobacterial phytochrome 1 ( $\mathrm{CPH} 1)$ was repurposed to induce homodimerization of proteins in living cells by red light. Using this domain, light-activated protein kinases were engineered that can be activated orthogonally from many fluorescent proteins and through mammalian tissue.

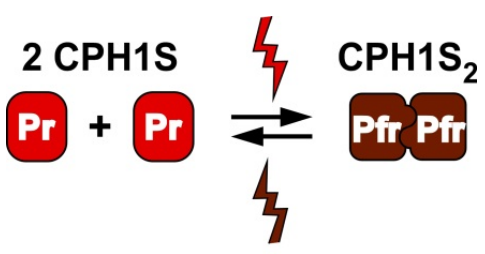

Eva Reichhart, Alvaro Ingles-Prieto, Alexandra-Madelaine Tichy, Catherine McKenzie and Harald Janovjak*

Page No. - Page No.

A Phytochrome Sensory Domain Permits Receptor Activation by Red Light 


\section{Table of Contents}

Experimental Section

Figures S1 to S8

Tables S1 to S5 


\section{Experimental Section}

\section{Phyotochrome sensory domains}

Gene fragments coding for the sensory domain of two phytochromes, $\mathrm{CPH} 1$ from Synechocystis PCC6803 and the phytochrome of Cyanothece sp. ATCC51142 (C.s.), were amplified from genomic DNA libraries using polymerase chain reaction (PCR) (oligonucleotides 1-4, Table S1). The sensory domain of the phytochrome of Nostoc sp. PCC7102 (N.s.) was amplified from cyanobacteria, which were lysed by boiling, using PCR (oligonucleotides 5 and 6, Table S1). In addition, gene fragments for the sensory domain of $\mathrm{CPH} 1$ and the phytochrome of Agrobacterium tumefaciens (A.t.) were synthesized with mammalian codon optimization according to the supplier's recommendation (Epoch Life Science, Inc.) and amplified using PCR (oligonucleotides 7-10, Table S1). Genes are given in Table S2 and S3.

\section{Receptor tyrosine kinase fusion proteins}

Phytochrome sensory domains were inserted into a mFGFR1 construct that was described previously ${ }^{[1]}$ using $\mathrm{PCR}$ and the Agel and Xmal restriction enzymes (see above for oligonucleotides). This construct contains the complete intracellular domain of mFGFR1, a myriostylation membrane anchor and a HA-epitope. rtrkB-CPH1S-o was generated using inverse PCR (oligonucleotides 11 and 12, Table S1). Starting from mFGFR1-CPH1S-o, amplification produced linear double-stranded DNA products with terminal SgrAI restriction sites that replace the mFGFR1 catalytic domain. Products were digested with SgrAl, ligated and propagated in E. coli cells. The rtrkB catalytic domain was then inserted using PCR and the BspEl and Agel restriction enzymes (oligonucleotides 13 and 14, Table S1). Point substitutions in mFGFR1-CPH1S-o (Y271F, Y272F and R195E; numbered relative to start methionine of red light-activated mFGFR1) were introduced using site-directed mutagenesis (oligonucleotides 1518, Table S1). For multi-color fluorescent reporter experiments, the CMV promoter in the mFGFR1-CPH1S-o expression vector was truncated for lower expression ${ }^{[2]}$ using inverse PCR followed by blunt end ligation (oligonucleotides 19 and 20, Table S1). All constructs were verified by DNA sequencing and sequences are given in Table S4.

\section{Fluorescent transcriptional reporters}

Fluorescence transcriptional reporters (Table S5) were generated by first removing the luciferase gene from the pGL4.33 vector (Promega) using inverse PCR and the Ascl restriction enzyme (oligonucleotides 21 and 22, Table S1). Genes coding for mCerulean3 or mCherry, kind 
gifts of R.Y. Tsien and M. Davidson, were inserted using PCR (oligonucleotides 23-26, Table S1).

\section{Cell culture}

HEK293 cells were maintained in DMEM and INS-1E cells ${ }^{[3]}$, a kind gift of $P$. Maechler, were maintained in RPMI-1640 in a humidified incubator with $5 \% \mathrm{CO}_{2}$ atmosphere $\left(37^{\circ} \mathrm{C}\right)$. DMEM was supplemented with $10 \%$ FBS, $100 \mathrm{U} / \mathrm{ml}$ penicillin and $0.1 \mathrm{mg} / \mathrm{ml}$ streptomycin, and RPMI1640 was additionally supplemented with $10 \mathrm{mM}$ HEPES, $1 \mathrm{mM}$ pyruvate, $2 \mathrm{mM}$ L-Glutamine and $50 \mu \mathrm{M} \beta$-mercaptoethanol. HEK293 cells were transfected using polyethylenimine (Polysciences) and INS-1E cells were transfected using Lipofectamine 2000 (Invitrogen/Life Technologies) (see below).

\section{Sensory domain expression and cell viability}

An expression plasmid based on pcDNA3.1(-) was used in which a BspEl restriction site was placed after the fluorescent protein $\mathrm{mVenus}^{[4]}$ and a glycine- and serine-rich linker. ${ }^{[1]} \mathrm{CPH} 1 \mathrm{~S}$, CPH1S-o and FKBP domains were inserted into this plasmid using PCR (see above for oligonucleotides and restriction enzymes). $5 \times 10^{4}$ HEK293 cells in each well of 96-well clear bottom plates coated with poly-L-ornithine (Sigma) were transfected with 5-10 ng expression plasmid. Expression was assessed by measuring mVenus fluorescence in a microplate reader (BioTek Synergy H1) $30 \mathrm{~h}$ after transfection. For viability measurements after fluorescence measurement cells were incubated for $2 \mathrm{~h}$ with thiazolyl blue tetrazolium bromide (Sigma) (0.5 $\mathrm{mg} / \mathrm{ml})$ followed by lysis with $70 \mu \mathrm{l}$ acidic isopropanol $(0.1 \mathrm{~N} \mathrm{HCl})$. Absorbance measurements were taken at $570 \mathrm{~nm}$ with $620 \mathrm{~nm}$ reference in the plate reader.

\section{MAPK/ERK pathway activation (luminescence)}

Activation of the MAPK/ERK pathway was assayed with the PathDetect Elk1 trans-Reporting System (Agilent). $5 \times 10^{4}$ HEK293 cells in each well of 96-well clear bottom plates were transfected with $210.3 \mathrm{ng}$ total plasmid (receptor, trans-activator and trans-reporter at a ratio of 1:30:600). $6 \mathrm{~h}$ after transfection, medium was replaced with $\mathrm{CO}_{2}$-independent reduced serum starve medium (Gibco/Life Technologies; supplemented with 0.5 \% FBS, 2 mM L-Glutamine, $100 \mathrm{U} / \mathrm{ml}$ penicillin and $0.1 \mathrm{mg} / \mathrm{ml}$ streptomycin), and $10 \mu \mathrm{M}$ phycocyanobilin (PCB; Livchem Logistics) was added to the cells in the dark. After overnight incubation $\left(37^{\circ} \mathrm{C}, 5 \% \mathrm{CO}_{2}\right)$, cells were either stimulated with light for $8 \mathrm{~h}$ or protected from light at $37{ }^{\circ} \mathrm{C}$ (see main text for wavelengths and intensities). Light intensities in an incubator equipped with 300 light emitting diodes was controlled with a dimmer and measured with a power meter (PM120VA, Thorlabs). 
Intensities at maximal output were 230 (red light, $\lambda \approx 630 \pm 5 \mathrm{~nm}$ ), 210 (green light, $\lambda \approx 530 \pm 5$ $\mathrm{nm}$ ) and 555 (blue light, $\lambda \approx 470 \pm 5 \mathrm{~nm}) \mu \mathrm{W} \mathrm{cm}{ }^{-2}$. Activation of receptors containing CPH1S-O fusion was observed for light intensities lower than $60 \mu \mathrm{W} \mathrm{cm}{ }^{-2}$. After incubation, plates were washed once with PBS and processed with Luciferase One-Glo Assay System (Promega) following the manufacturer's instructions. Luminescence was detected with the microplate reader.

\section{MAPK/ERK pathway activation (multi-color fluorescence)}

$5 \times 10^{4}$ cells in each well of 96-well clear bottom plates were transfected with $251 \mathrm{ng}$ total plasmid (viability reporter, signaling reporter and receptor at a ratio of 1:100:150). $16 \mathrm{~h}$ after transfection, medium was replaced with $\mathrm{CO}_{2}$-independent reduced serum starve medium and incubated in the dark $\left(37{ }^{\circ} \mathrm{C}, 5 \% \mathrm{CO}_{2}\right)$. After $5 \mathrm{~h}, 10 \mu \mathrm{M}$ PCB and, where required, $0.1 \mu \mathrm{M}$ Trametinib (GSK1120212) or $10 \%$ DMSO were added to each well and cells were incubated for further $4 \mathrm{~h}$ in the dark. Cells were then stimulated either with red light $\left(I=6.2 \mu \mathrm{W} \mathrm{cm}{ }^{-2}, \lambda \approx 630\right.$ $\pm 5 \mathrm{~nm})$, treated with FBS $(10 \%)$ and PMA $(10 \mathrm{ng} / \mathrm{ml})$ or kept in the dark for $18 \mathrm{~h}$. After incubation, medium was replaced by PBS and fluorescence was measured with the microplate reader (mCerulean3: $\lambda \mathrm{Ex} / \mathrm{Em}=433 / 475 \mathrm{~nm}$, mCherry: $\lambda \mathrm{Ex} / \mathrm{Em}=588 / 630 \mathrm{~nm}$ ).

\section{Immunoblotting (HEK293 cells)}

$1 \times 10^{6}$ HEK293 cells in a $35 \mathrm{~mm}$ dish were transfected with $4.02 \mu \mathrm{g}$ total plasmid per dish (receptor and empty vector and receptor at a ratio of 1:200). $6 \mathrm{~h}$ after transfection, medium was replaced with $1.5 \mathrm{ml}$ reduced serum starve medium supplemented with $10 \mu \mathrm{M}$ PCB. After $20 \mathrm{~h}$, cells were illuminated for $3 \mathrm{~min}$ with red light $\left(I=6.2 \mu \mathrm{W} \mathrm{cm}{ }^{-2}, \lambda \approx 630 \pm 5 \mathrm{~nm}\right)$. Cells were then either immediately, or after additional 5,15 or 30 min in the dark, washed with ice-cold PBS and lysed on ice in $250 \mu \mathrm{l}$ lysis buffer per dish. Control cells, control cells without PCB treatment and mock transfected (m.t) cells were not illuminated and washed and lysed immediately. Lysates were shaken for $30 \mathrm{~min}$ at $4{ }^{\circ} \mathrm{C}$ and centrifuged for $20 \mathrm{~min}$ at $12000 \mathrm{rpm}$ at $4{ }^{\circ} \mathrm{C} .20 \mu$ lysate per lane were separated by SDS-PAGE and electro-blotted onto PVDF membranes. Blots were incubated with primary antibodies (pERK1/2 \#9101, dilution 1:1000; ERK1/2 \#9102, dilution 1:1000; Akt \#9272, dilution 1:1000; pAkt \#4060, dilution 1:2000; Cell Signaling Technology; ERK2 sc-153, dilution 1:1000; Santa Cruz Biotechnology) in blocking solution (5\% BSA in TBST) overnight at $4{ }^{\circ} \mathrm{C}$. Secondary antibody (Goat anti-rabbit $\lg G(H+L)-H R P$ conjugated, Biorad) was applied at a dilution of 1:10000 for $2 \mathrm{~h}$ at RT. 


\section{Synthetic tissues and MAPK/ERK pathway activation}

Synthetic tissues whose spectral properties match those of human skin, skull and muscle ${ }^{[5]}$ were prepared by supplementing high purity $2 \%$ agarose gels (Carl Roth) with dyes (Sigma) depending on tissue type (Figure S5). Synthetic skin was generated by supplementing $104.5 \mathrm{ml}$ gel with $50 \mu \mathrm{g}$ tartrazine and $3 \mu \mathrm{g}$ amaranth. Synthetic muscle was generated by supplementing with $15 \mu \mathrm{g}$ tartrazine and $15 \mu \mathrm{g}$ amaranth. Synthetic skull was generated by supplementing 31.4 $\mathrm{ml}$ gel with $75 \mu \mathrm{g}$ tartrazine, $55 \mu \mathrm{g}$ allura red AC, $10 \mu \mathrm{g}$ amaranth, $25 \mu \mathrm{g}$ prussian blue and 50 $\mu \mathrm{g}$ brilliant blue. $10 \mathrm{~mm}$ of synthetic tissue correspond to $10 \mathrm{~mm}$ of animal tissue, except for skin which has 20-fold higher absorption (in this case, $10 \mathrm{~mm}$ of synthetic tissue correspond to 0.5 $\mathrm{mm}$ of mammalian skin). HEK293 cells transiently transfected with rtrkB-CPH1S-o were illuminated through the synthetic tissues and further processed for luminescence measurements as described above.

\section{Determination of tissue penetration through animal tissue}

For measuring light penetration through head, the lower jaw and the palate bone of three shaved mouse heads were removed to create an opening (light that penetrated through the shaved scalp, the skull and the whole brain was measured). For mouse abdomen, shaved mouse torso was opened (light that penetrated through shaved skin, fat, muscle, spine and organs was measured). For illumination, a bright lamp (DG4, Sutter instruments) and a dish covered with black tape with a window was placed above a sensor connected to a power meter (Figure S7b). Three measurements were acquired each first without sample (to determine the initial light intensity, $I_{0}$, in $\mu \mathrm{W} \mathrm{cm}{ }^{-2}$ ) and then with the sample (to determine transmission, $T$, in $\mu \mathrm{W} \mathrm{cm}{ }^{-2}$ ). All measurements were made in triplicates and penetration was calculated as $T / I_{0}$.

\section{Activation of INS-1E cells through animal tissue}

Because the synthetic tissues were optimized to mimic absorption but not scattering properties, we also performed experiments with mouse tissues. $1.5 \times 10^{6}$ INS-1E cells were seeded in a 35 $\mathrm{mm}$ dish and transfected with $2.5 \mu \mathrm{g}$ total DNA per dish (receptor and empty vector at a ratio of 1:50). $9.5 \mathrm{~h}$ after transfection, medium was replaced with $1.5 \mathrm{ml}$ reduced serum starve medium supplemented $10 \mu \mathrm{M}$ PCB and incubated for $18 \mathrm{~h}$ in the dark. Mouse abdomen including shaved skin, fat, muscle, and spine was placed in a $35 \mathrm{~mm}$ cell culture dish. The dish was covered with black tape, except for a window at its bottom and top. Cells were illuminated for 15 min with red light $\left(I=3.0 \mathrm{~mW} \mathrm{~cm}^{-2}, \lambda \approx 647 \pm 35 \mathrm{~nm}\right)$ through the mouse abdomen. Cells were then immediately washed, lysed, and processed as described above (dark and mock 
transfection (m.t) controls were also treated as described above). $30 \mu \mathrm{l}$ lysate per lane were separated by SDS-PAGE and electro-blotted onto PVDF membranes. Blots were incubated with primary antibody (pERK1/2 \#9101, dilution 1:1000, Cell Signaling) in blocking solution overnight at $4{ }^{\circ} \mathrm{C}$ and secondary antibody for processing as described above. 


\section{Supporting Figures}

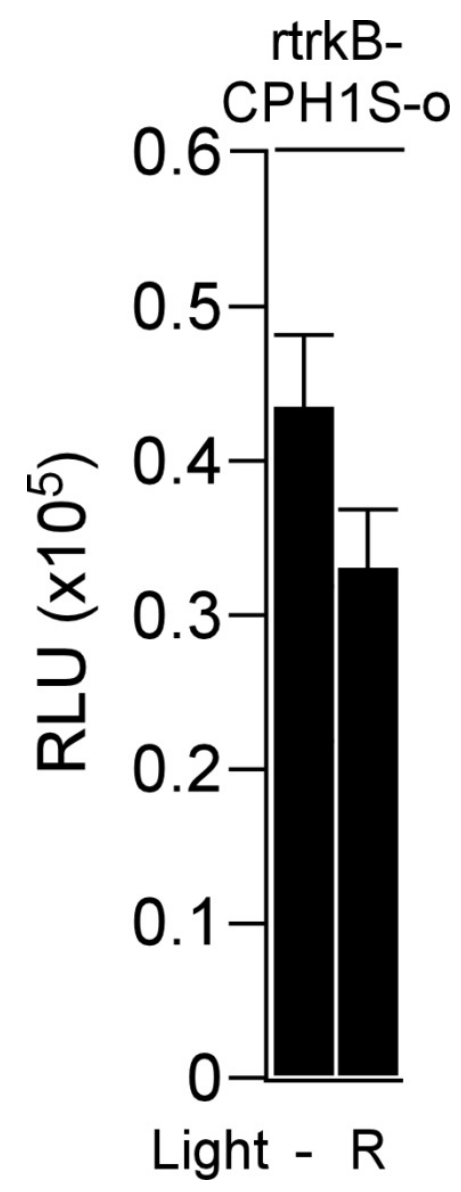

Figure S1: MAPK/ERK pathway activation in HEK293 cells transfected with rtrkB-CPH1S-o in response to red light $(R)$ stimulation $\left(I=6.2 \mu \mathrm{W} \mathrm{cm}^{-2}, \lambda \approx 630 \pm 5 \mathrm{~nm}\right)$ in the absence of added PCB. Pathway activation is expressed as reporter gene levels. Mean values \pm SEM for one independent experiment performed in triplicates are shown. 


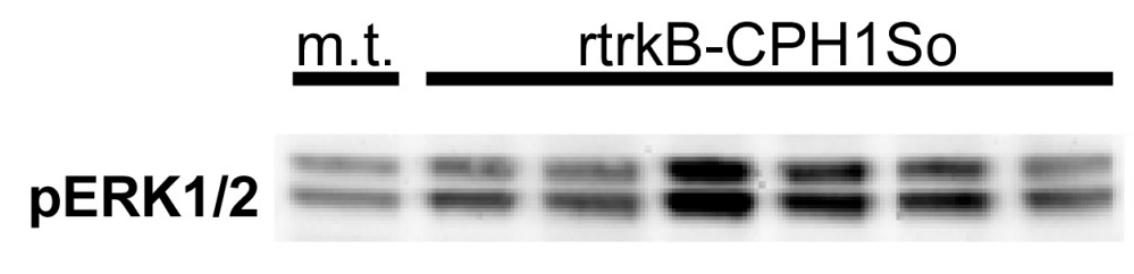

ERK1/2

PAKT

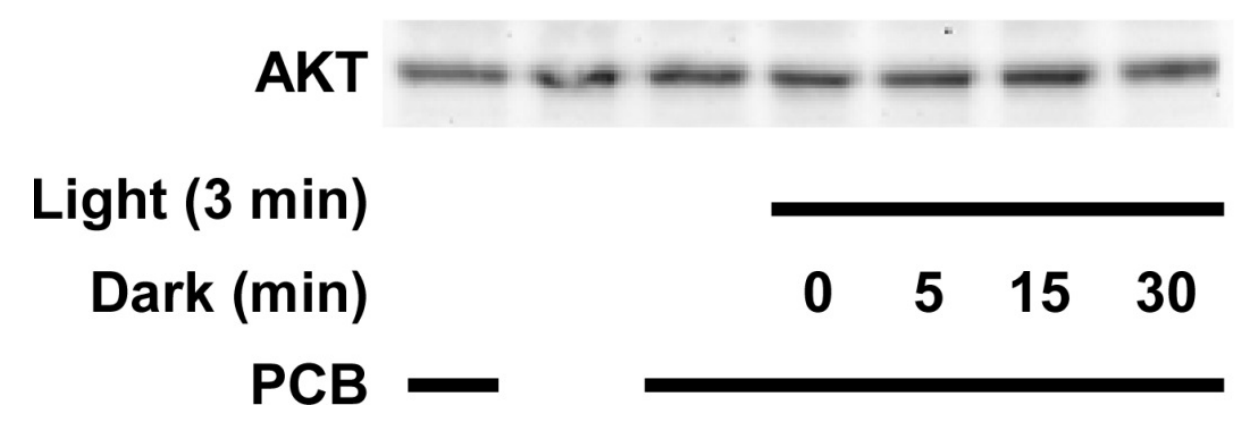

Figure S2: Phosphorylation of ERK1/2 (pERK1/2) and Akt (pAkt) in HEK293 cells transfected with rtrkB-CPH1S-o in response to red light stimulation $\left(I=6.2 \mu \mathrm{W} \mathrm{cm}{ }^{-2}, \lambda \approx 630 \pm 5 \mathrm{~nm}, 3 \mathrm{~min}\right)$ followed by indicated duration of darkness. 


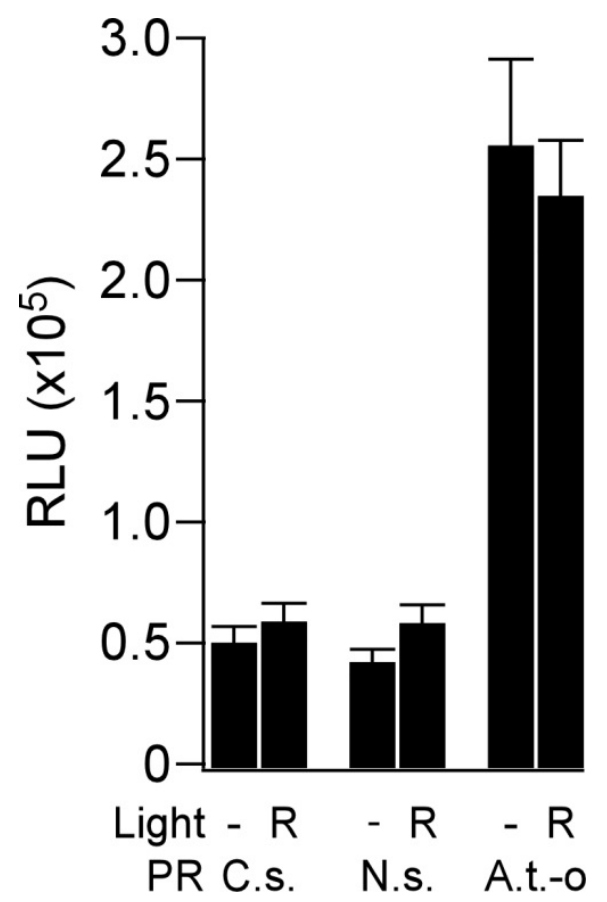

Figure S3: MAPK/ERK pathway activation in HEK293 cells transfected with chimeric proteins of mFGFR1 and different photoreceptors from different species in response to red light $(I=6.2 \mu \mathrm{W}$ $\mathrm{cm}^{-2}, \lambda \approx 630 \pm 5 \mathrm{~nm}$ ). PR: Photoreceptor, C.s.: Cyanothece sp. ATCC 51142, N.s.: Nostoc sp. PCC 7120 and A.t.-o: A. tumefaciens. Pathway activation is expressed as reporter gene levels. Mean values \pm SEM for one to seven independent experiments performed in triplicates are shown. 


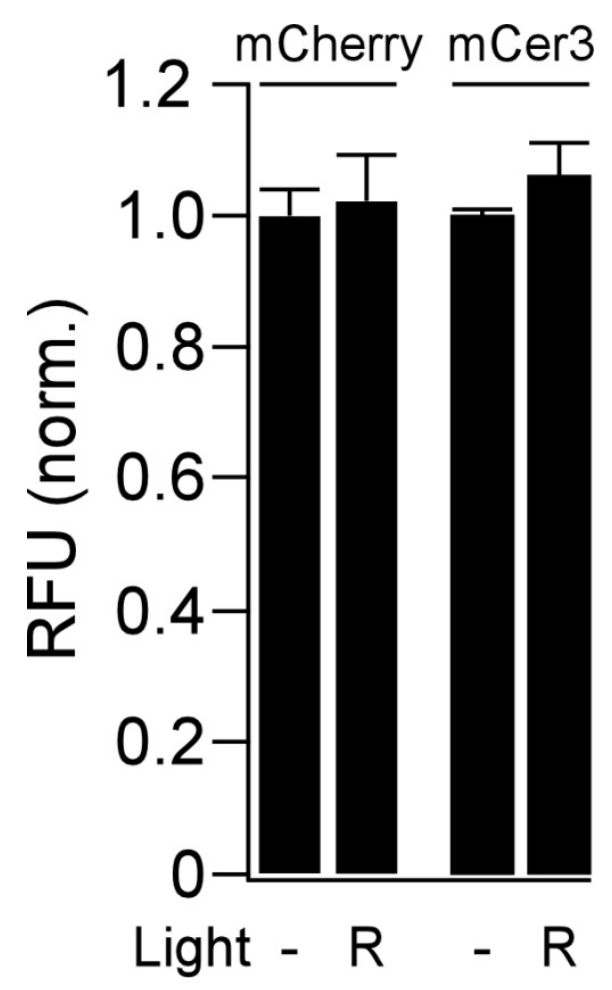

Figure S4: Fluorescence intensity measurement of CMV-mCherry and CMV-mCerulean3 after $18 \mathrm{~h}$ of red light illumination $\left(I=6.2 \mu \mathrm{W} \mathrm{cm}{ }^{-2}, \lambda \approx 630 \pm 5 \mathrm{~nm}\right.$ ). Mean values $\pm \mathrm{SEM}$ for three to four independent experiments performed at least in triplicates are shown. 
a)

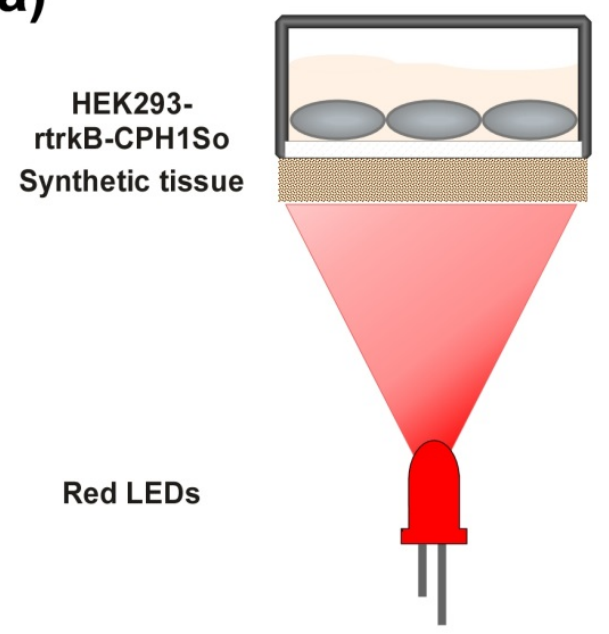

c)

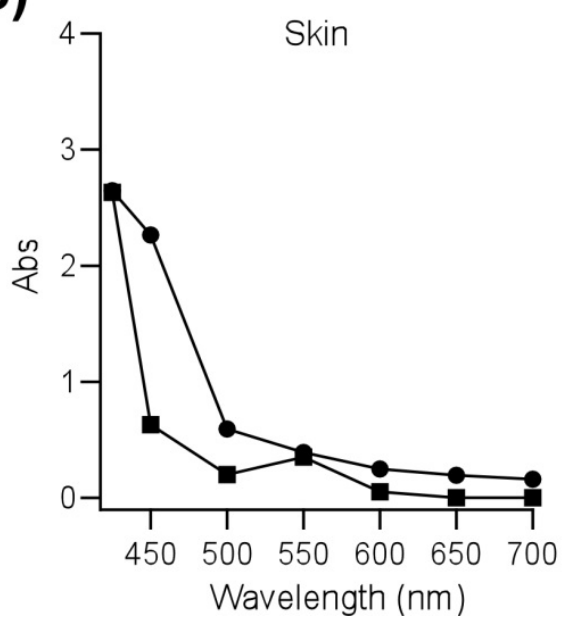

b)

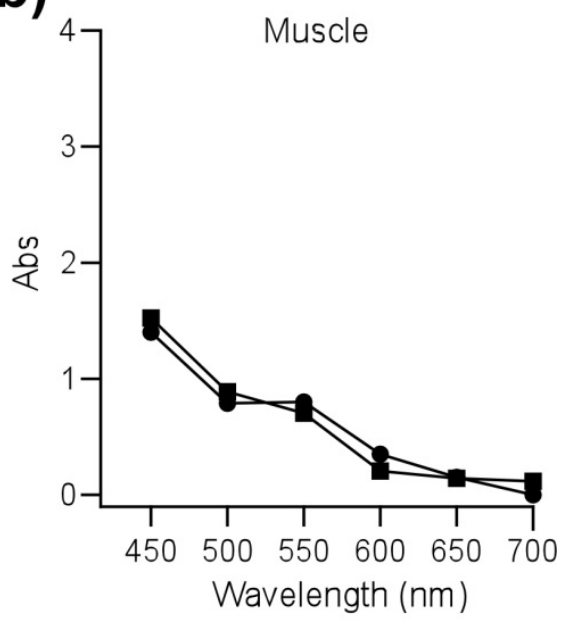

d)

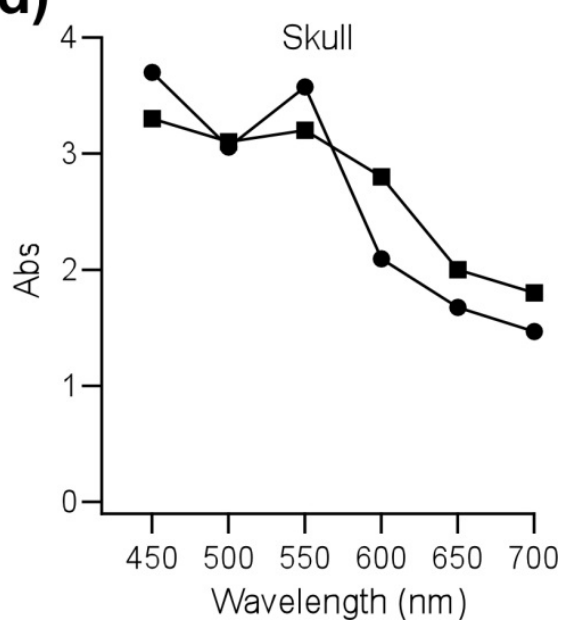

Figure S5: a) HEK293 cells transfected with rtrkB-CPH1S-o were illuminated with red light from the bottom through synthetic tissues in a 96-well clear bottom plate (the sides of the plates were covered with black tape). b-d) Absorption properties of mammalian $10 \mathrm{~mm}$ muscle b), $0.5 \mathrm{~mm}$ skin c) and $10 \mathrm{~mm}$ skull d) (circles; data taken from literature) ${ }^{[5]}$ and of the corresponding synthetic tissues produced by spiking agarose matrices with synthetic organic dyes (squares, see Experimental Procedures). 


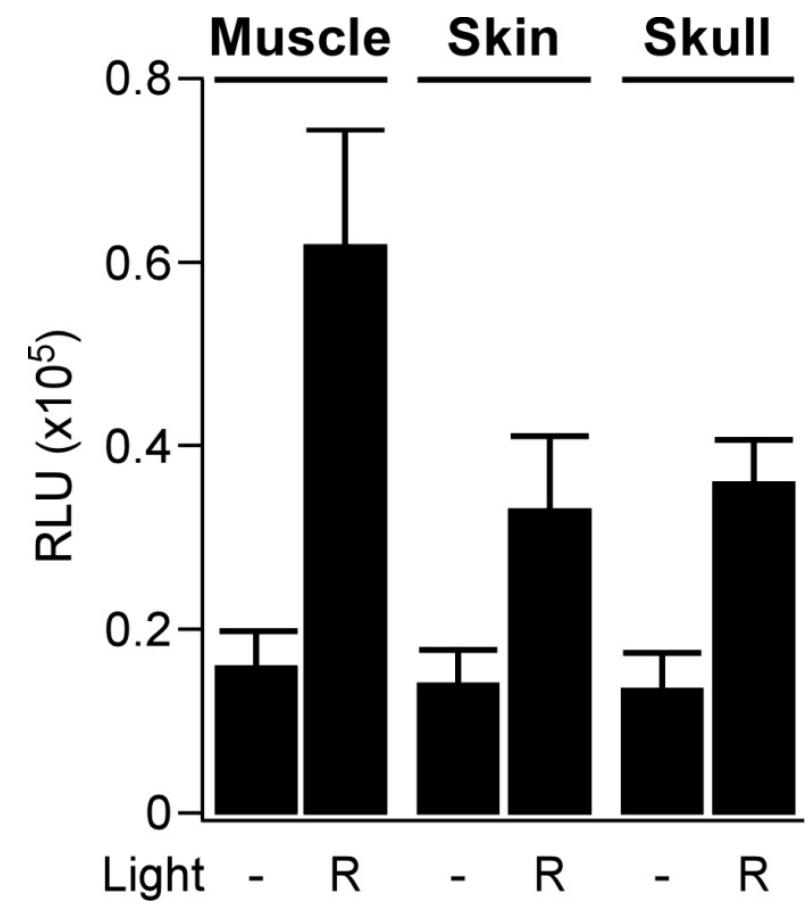

Figure S6: Activation of MAPK/ERK pathway in HEK293 cells transfected with rtrkB-CPH1S-o illuminated $\left(I=6.2-17.5 \mu \mathrm{W} \mathrm{cm}{ }^{-2}, \lambda \approx 630 \pm 5 \mathrm{~nm}\right)$ through synthetic tissues mimicking $10 \mathrm{~mm}$ muscle, $0.5 \mathrm{~mm}$ skin or $3 \mathrm{~mm}$ skull. Mean values \pm SEM for one to three independent experiments performed in triplicates are shown. 


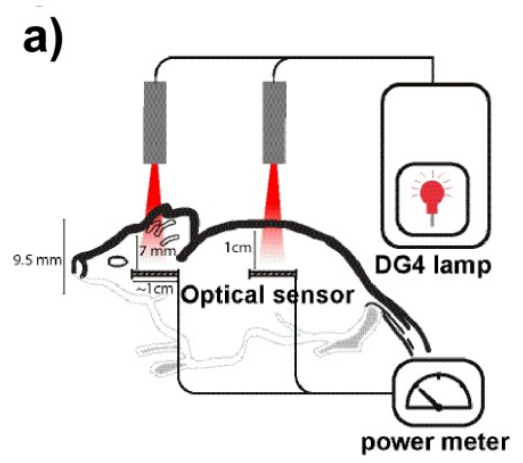

b)
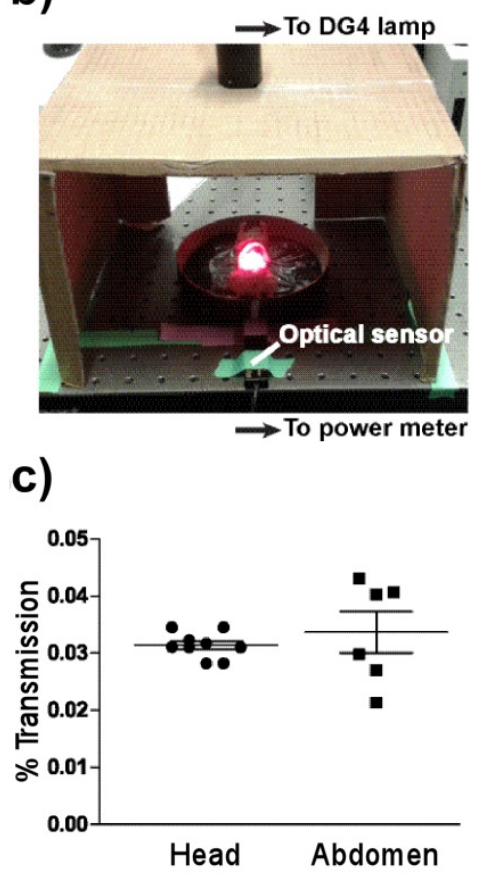

Figure S7: a) and b) Set-up for measuring light penetration through the head and abdomen of a mouse. Red light was aimed above the shaved mouse head (thickness $\approx 7 \mathrm{~mm}$ ) or above the opened mouse abdomen (thickness $\approx 10 \mathrm{~mm}$ ). An optical sensor (diameter $=10 \mathrm{~mm}$ ) connected to a power meter was placed directly under the ventral part of the brain or under the shaved abdomen of the mouse. c) Transmission of red light through head (circles; three samples measured in triplicate) and abdomen (squares; two samples measured in triplicate). Error bars indicate SEM. 


\section{a)}

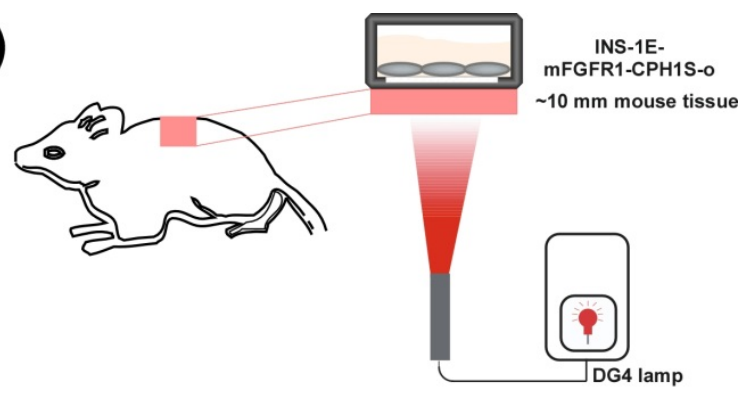

b)

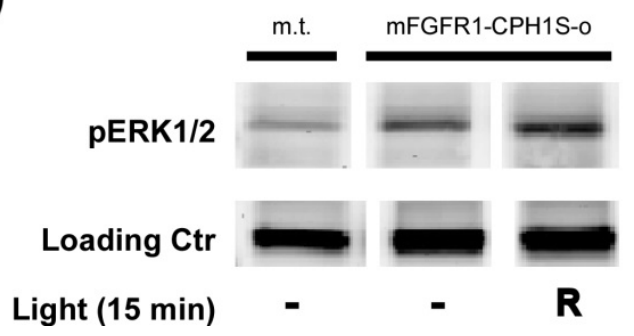

Figure S8: a) INS-1E cells transfected with mFGFR1-CPH1S-o were stimulated through mouse tissue (thickness $\approx 10 \mathrm{~mm}$ ) with red light $\left(I=3.0 \mathrm{~mW} \mathrm{~cm}^{-2}, \lambda \approx 647 \pm 35 \mathrm{~nm}\right.$ ). The lamp was located directly below the mouse tissue to ensure all light passing through the tissue. b) Phosphorylation of ERK1/2 (pERK1/2) in stimulated INS-1E cells. 


\section{Supporting Tables}

Table S1. Oligonucleotides utilized in gene construction. Restriction sites are underlined

\begin{tabular}{|c|c|}
\hline Name & Sequence \\
\hline 1: CPH1S_Xmal_F & GCTACCCGGGGCCACCACCGTACAACTCAG \\
\hline 2: CPH1S_Xmal_R & GCTACCCGGGTTCTTCTGCCTGGCGCAAAATG \\
\hline 3: C.s._Xmal_F & GATGCCCGGGATTAGTAATGTTAAAACCAGTCAAGAC \\
\hline 4: C.s._Xmal_R & GATGCCCGGGTTCGTCGGCTTGTCGGAGAATAATG \\
\hline 5: N.s._Agel_F & GATGACCGGTAGAATAGACGTAGAATCACAAAATATTAATG \\
\hline 6: N.s._Xmal_R & GATGCCCGGGTTCATCGGCTTGGCGTAGAACG \\
\hline 7: CPH1S-o_Xmal_F & GATCCCCGGGGCAACTACTGTTCAACTGTCTGATCAATCTCTG \\
\hline 8: CPH1S-o_Xmal_R & GATCCCCGGGTTCTTCAGCTTGGCGCAGAATCAGGTT \\
\hline 9: A.t._Agel_F & GATCACCGGTCAGCGTGAACGTCTGGAGAAAGTCATGT \\
\hline 10: A.t._Agel_R & GATCACCGGTTTCTTCAGTTTTGCGCAGGACGATGC \\
\hline 11: $\mathrm{mF}$ _inverse_SgrAl_F & GATCCACCGGTGGAGCAACTACTGTTCAACTGTCTG \\
\hline 12: $\mathrm{mF}$ _inverse_SgrAl_R & GATCCACCGGTGACGTCGAGGCGCTG \\
\hline 13: rtrkB_BspEI_F & GATCTCCGGAAAGTTTGGCATGAAAG \\
\hline 14: rtrkB_Agel_R & CAGAAACCGGTGCCTAGGATGTCCAG \\
\hline 15: mF_YY271/2FF_F & GAGACATTCATCATATCGACTTCTTCAAGAAAACCACCAACGGCC \\
\hline 16: mF_YY271/2FF_R & GGCCGTTGGTGGTTTTCTTGAAGAAGTCGATATGATGAATGTCTC \\
\hline 17: mF_R195E_F & TACAGGCCCGGGAGCCTCCTGGGCTGGAGTACTGCTATAA \\
\hline 18: mF_R195E_R & TTATAGCAGTACTCCAGCCCAGGAGGCTCCCGGGCCTGTA \\
\hline 19: truncated CMV_pcDNA3.1(-)_F & TGGGAGGTCTATATAAGCAGAGC \\
\hline 20: truncated CMV_pcDNA3.1(-)_R & GGCGGGCCATTTACCGTAAG \\
\hline 21: pGL4_inverse_Ascl_F & GATCATGGCGCGCCCTAAGGCCGCGACTCTAGAGTC \\
\hline 22: pGL4_inverse_Ascl_R & ATGATCGGCGCGCCGGTGGCTTTACCAACAGTAC \\
\hline 23: mCerulean3_Ascl_F & CATCAGGCGCGCCATGGTGAGCAAGGGGCGAGGAG \\
\hline 24: mCerulean3_Ascl_R & GATCAGGCGCGCCCTAGGACTTGTACAGCTCGTCCATG \\
\hline 25: mCherry_Ascl_F & CATCAGGCGCGCCATGGTGAGCAAGGGCGAGGAGG \\
\hline 26: mCherry_Ascl_R & GATCAGGCGCGCCTTACTTGTACAGCTCGTCCATGCC \\
\hline
\end{tabular}


Table S2. Protein sequences of full length proteins and sensory domains. Uniprot identifiers are given in parentheses

\begin{tabular}{|c|c|}
\hline Name & Sequence \\
\hline CPH1 (Q55168) & $\begin{array}{l}\text { MATTVQLSDQSLRQLETLAIHTAHLIQPHGLVVVLEPDLTISQISANCTGILGRSPEDL } \\
\text { LGRTLGEVFDSFQIDPIQSRLTAGQISSLNPSKLWARVMGDDFVIFDGVFHRNSDGLL } \\
\text { VCELEPAYTSDNLPFLGFYHMANAALNRLRQQANLRDFYDVIVEEVRRMTGFDRVML } \\
\text { YRFDENNHGDVIAEDKRDDMEPYLGLHYPESDIPQPARRLFIHNPIRVIPDVYGVAVPL } \\
\text { TPAVNPSTNRAVDLTESILRSAYHCHLTYLKNMGVGASLTISLIKDGHLWGLIACHHQT } \\
\text { PKVIPFELRKACEFFGRVVFSNISAQEDTETFDYRVQLAEHEAVLLDKMTTAADFVEGL } \\
\text { TNHPDRLLGLTGSQGAAICFGEKLILVGETPDEKAVQYLLQWLENREVQDVFFTSSLS } \\
\text { QIYPDAVNFKSVASGLLAIPIARHNFLLWFRPEVLQTVNWGGDPNHAYEATQEDGKIE } \\
\text { LHPRQSFDLWKEIVRLQSLPWQSVEIQSALALKKAIVNLILRQAEELAQLARNLERSNA } \\
\text { DLKKFAYIASHDLQEPLNQVSNYVQLLEMRYSEALDEDAKDFIDFAVTGVSLMQTLIDD } \\
\text { ILTYAKVDTQYAQLTFTDVQEVVDKALANLKQRIEESGAEIEVGSMPAVMADQIQLMQ } \\
\text { VFQNLIANGIKFAGDKSPKIKIWGDRQEDAWVFAVQDNGIGIDPQFFERIFVIFQRLHTR } \\
\text { DEYKGTGMGLAICKKIIEGHQGQIWLESNPGEGSTFYFSIPIGN }\end{array}$ \\
\hline CPH1S(-0) & $\begin{array}{l}\text { ATTVQLSDQSLRQLETLAIHTAHLIQPHGLVVVLQEPDLTISQISANCTGILGRSPEDLL } \\
\text { GRTLGEVFDSFQIDPIQSRLTAGQISSLNPSKLWARVMGDDFVIFDGVFHRNSDGLLV } \\
\text { CELEPAYTSDNLPFLGFYHMANAALNRLRQQANLRDFYDVIVEEVRRMTGFDRVMLY } \\
\text { RFDENNHGDVIAEDKRDDMEPYLGLHYPESDIPQPARRLFIHNPIRVIPDVYGVAVPLT } \\
\text { PAVNPSTNRAVDLTESILRSAYHCHLTYLKNMGVGASLTISLIKDGHLWGLIACHHQTP } \\
\text { KVIPFELRKACEFFGRVVFSNISAQEDTETFDYRVQLAEHEAVLLDKMTTAADFVEGLT } \\
\text { NHPDRLLGLTGSQGAAICFGEKLILVGETPDEKAVQYLLQWLENREVQDVFFTSSLSQI } \\
\text { YPDAVNFKSVASGLLAIPIARHNFLLWFRPEVLQTVNWGGDPNHAYEATQEDGKIELH } \\
\text { PRQSFDLWKEIVRLQSLPWQSVEIQSALALKKAIVNLILRQAEE }\end{array}$ \\
\hline $\begin{array}{l}\text { Phytochrome of C.s. } \\
\text { (B1X1A4) }\end{array}$ & $\begin{array}{l}\text { MISNVKTSQDINLQRLEELQIHLWGKIQPHGVLFVIDESNLEILQTSSNTKQFFGITPKEII } \\
\text { KLTLDDIFDSFQIEQLKTGLESNNLDFINPTKLWARVDGDNYVIFDGIFHRNVEGFLILEL } \\
\text { EPAISQENIPFLSFYHLAKASITQLQTNANLTDFCQIIVKEVRKMTGFDRVMLYKFDEDD } \\
\text { HGEVIAEDKLEQLDPYLGLHYPASDIPLPARRLFSSNYIRLIPDAKATGVDLFPKLHPLN } \\
\text { DTALDLTHSILRSASPCHLEYLHNMGVGASLTISLIDEGKLWGIIACHHLTPKYVPYELR } \\
\text { KACEFLGQVVFAEISAKEETKDYDYRMKLTAIQGRLVESMTQADTFIEGLIKSDQKLLE } \\
\text { LTSSQGVAVCVGDDYSLIGKTPKNEEVKYLLQWLKKEINEEVFSTPSLPNLYADARNF } \\
\text { KDVGSGLLAIKISHRNYILWFRPEVIQTVNWGGDPSKAYEMENIDGNLKLCPRKSFEL } \\
\text { WKETVRLTSLSWKPVEIKAALGLKEAIVNIILRQADELAQLAHDLELSNAELKKFAYVAS } \\
\text { HDLQEPLNQVSNYVQLLEMRYDEALDEDAKEFINFAVEGVSLMQTLIDDVLAYSKVDM } \\
\text { RDIEFQLTESETALEKAIANLRGRIAETNAIITHDPLPTVMADGTQLIQLFLNLLSNAIKFR } \\
\text { KEVTPEIHIQAQRLEDEWLFSVQDNGMGIDPRFSDRIFIIFQRLHTRDEYPGTGMGLAI } \\
\text { CKKIMECHRGKIWVESQLGQGATFYFTIPVGGKQRDRKRGSTR }\end{array}$ \\
\hline C.s. & $\begin{array}{l}\text { ISNVKTSQDINLQRLEELQIHLWGKIQPHGVLFVIDESNLEILQTSSNTKQFFGITPKEIIK } \\
\text { LTLDDIFDSFQIEQLKTGLESNNLDFINPTKLWARVDGDNYVIFDGIFHRNVEGFLILELE } \\
\text { PAISQENIPFLSFYHLAKASITQLQTNANLTDFCQIIVKEVRKMTGFDRVMLYKFDEDDH } \\
\text { GEVIAEDKLEQLDPYLGLHYPASDIPLPARRLFSSNYIRLIPDAKATGVDLFPKLHPLND }\end{array}$ \\
\hline
\end{tabular}




\begin{tabular}{|c|c|}
\hline & $\begin{array}{l}\text { TALDLTHSILRSASPCHLEYLHNMGVGASLTISLIDEGKLWGIIACHHLTPKYVPYELRK } \\
\text { ACEFLGQVVFAEISAKEETKDYDYRMKLTAIQGRLVESMTQADTFIEGLIKSDQKLLELT } \\
\text { SSQGVAVCVGDDYSLIGKTPKNEEVKYLLQWLKKEINEEVFSTPSLPNLYADARNFKD } \\
\text { VGSGLLAIKISHRNYILWFRPEVIQTVNWGGDPSKAYEMENIDGNLKLCPRKSFELWK } \\
\text { ETVRLTSLSWKPVEIKAALGLKEAIVNIILRQADE }\end{array}$ \\
\hline $\begin{array}{l}\text { Phytochrome of N.s. } \\
\text { (Q9LCC2) }\end{array}$ & $\begin{array}{l}\text { MRIDVESQNINVTSLKEAPIHLSGQIQPHGVLLVLEEPGLKILQVSNNTWGILGINAENIL } \\
\text { QKKLEDLLDSFQIERIQSGLSSGNLEFINPTKIWIRKKGDDYAVFDAVFHRNTEGFLILE } \\
\text { LEPAITQENIPFLSFYHLAKASINQLQKTANLRDFCQIIVQEVRKVTDFDRVMLYKFDDD } \\
\text { GHGSVIAEEKLDSLEPYLGLHYPESDIPKPARKLFISNSIRVIPNAQAQAIQMIPALNPVS } \\
\text { DRPVDLTNSILRSAANCHLEYLHNMGVGASLTISLIKDNKLWGLIACHHLSAKYVSYEL } \\
\text { RKACEFLGRVIFAEISAREETEDYDYRMNLTHIQSLLVEYMSQEDNFVDGLIKHQPSLL } \\
\text { DLTSAQGAAVCFGDHCTLIGETPKAEDLVFLVQWLKNNVEEEVFYTDSLPQVYPDAE } \\
\text { RYKNVASGLLAIPISQRNYVLWFRPEVIQTVNWGGDPNQPFEVNKLDGNVRLCPRKS } \\
\text { FELWKETVRLTSLPWRYVEIRAALELRKAIVNIVLRQADELAQLAHDLERSNAELKKFA } \\
\text { YVASHDLQEPLNQVANYVQLLEMRYQDQDADANEFITFAVEGVSLMQTLIDDVLAYS } \\
\text { KVDTQAIAFQLTEVEKALDKALGNLRQRIAETGANITHDPLPTVMAGSTQLMQLFQNLI } \\
\text { ANAIKFRSEEAPQIHIGAERLEDEWLFSVRDNGIGIDPQFSDRIFVIFQRLHTRDEYHGT } \\
\text { GMGLAICKKIIECHRGRIWVESQLGEGATFYFTIPVGGRERERRNGRKTQNNLFS }\end{array}$ \\
\hline N.s. & $\begin{array}{l}\text { RIDVESQNINVTSLKEAPIHLSGQIQPHGVLLVLEEPGLKILQVSNNTWGILGINAENILQ } \\
\text { KKLEDLLDSFQIERIQSGLSSGNLEFINPTKIWIRKKGDDYAVFDAVFHRNTEGFLILELE } \\
\text { PAITQENIPFLSFYHLAKASINQLQKTANLRDFCQIIVQEVRKVTDFDRVMLYKFDDDGH } \\
\text { GSVIAEEKLDSLEPYLGLHYPESDIPKPARKLFISNSIRVIPNAQAQAIQMIPALNPVSDR } \\
\text { PVDLTNSILRSAANCHLEYLHNMGVGASLTISLIKDNKLWGLIACHHLSAKYVSYELRK } \\
\text { ACEFLGRVIFAEISAREETEDYDYRMNLTHIQSLLVEYMSQEDNFVDGLIKHQPSLLDL } \\
\text { TSAQGAAVCFGDHCTLIGETPKAEDLVFLVQWLKNNVEEEVFYTDSLPQVYPDAERY } \\
\text { KNVASGLLAIPISQRNYVLWFRPEVIQTVNWGGDPNQPFEVNKLDGNVRLCPRKSFEL } \\
\text { WKETVRLTSLPWRYVEIRAALELRKAIVNIVLRQADE }\end{array}$ \\
\hline Phytochrome of A.t. & $\begin{array}{l}\text { MQRERLEKVMSSHTPKLDSCGAEPIHIPGAIQEHGALLVLSAREFSVVQASDNLANYIG } \\
\text { VDLPIGAVATEANLPFISVLSAWYSGEESNFRYAWAEKKLDVSAHRSGTLVILEVEKAG } \\
\text { VGESAEKLMGELTSLAKYLNSAPSLEDALFRTAQLVSSISGHDRTLIYDFGLDWSGHV } \\
\text { VAEAGSGALPSYLGLRFPAGDIPPQARQLYTINRLRMIPDVDYKPVPIRPEVNAETGAV } \\
\text { LDMSFSQLRSVSPVHLEYMRNMGTAASMSVSIVVNGALWGLIACHHATPHSVSLAVR } \\
\text { EACDFAAQLLSMRIAMEQSSQDASRRVELGHIQARLLKGMAAAEKWVDGLLGGEGE } \\
\text { REDLLKQVGADGAALVLGDDYELVGNTPSREQVEELILWLGEREIADVFATDNLAGNY } \\
\text { PTAAAYASVASGIIAMRVSELHGSWLIWFRPEVIKTVRWGGDPHKTVQESGRIHPRKS } \\
\text { FEIWKEQLRNTSFPWSEPELAAARELRGAIIGIVLRKTEEMADLTRELQRTNKELEAFS } \\
\text { YSVSHDLRAPFRHIVGFAQLLRERSDALDEKSLHYLQMISEAALGAGRLVDDLLNFSQ } \\
\text { LGRTQLTLKPVDMQKVVSEVRRSLSHAVSDRQIEWRIGALPVIFGDPTLLRQVWYNLI } \\
\text { ENAIKYSSREPVSIITISAVETEDDVTYSVEDNGVGFDMAYYNKLFGVFQRLQRVEDFE } \\
\text { GTGIGLALVRRIVERHHGLVGAEGTVGEGATFSFTLPVTKVEEEKIA }\end{array}$ \\
\hline A.t.(-o) & QRERLEKVMSSHTPKLDSCGAEPIHIPGAIQEHGALLVLSAREFSVVQASDNLANYIGV \\
\hline
\end{tabular}




\begin{tabular}{|l|l|}
\hline GLPIGAVATEANLPFISVLSAWYSGEESNFRYAWAEKKLDVSAHRSGTLVILEVEKAGV \\
& GESAEKLMGELTSLAKYLNSAPSLEDALFRTAQLVSSISGHDRTLIYDFGLDWSGHVV \\
& AEAGSGALPSYLGLRFPAGDIPPQARQLYTINRLRMIPDVDYKPVPIRPEVNAETGAVL \\
& DMSFSQLRSVSPVHLEYMRNMGTAASMSVSIVVNGALWGLIACHHATPHSVSLAVRE \\
& ACDFAAQLLSMRIAMEQSSQDASRRVELGHIQARLLKGMAAAEKWVDGLLGGEGER \\
& EDLLKQVGADGAALVLGDDYELVGNTPSREQVEELILWLGEREIADVFATDNLAGNYP \\
& TAAAYASVASGIIAMRVSELHGSWLIWFRPEVIKTVRWGGDPHKTVQESGRIHPRKSF \\
& EIWKEQLRNTSFPWSEPELAAARELRGAIIGIVLRKTEE \\
\hline
\end{tabular}


Table S3. DNA sequences of codon-optimized sensory domains

\begin{tabular}{|c|c|}
\hline Name & Sequence \\
\hline CPH1S-O & $\begin{array}{l}\text { GCAACTACTGTTCAACTGTCTGATCAATCTCTGCGTCAACTGGAAACTCTGGCTATCCACA } \\
\text { CCGCGCATCTGATCCAGCCGCACGGTCTGGTAGTCGTCCTGCAAGAACCGGACCTGACC } \\
\text { ATCAGCCAGATCTCTGCGAACTGTACCGGTATCCTGGGCCGTAGCCCGGAAGATCTGCT } \\
\text { GGGTCGTACTCTGGGCGAGGTATTCGATTCTTTTCAGATTGATCCGATCCAGTCTCGTCT } \\
\text { GACCGCAGGTCAGATTTCCAGCCTGAACCCGTCCAAGCTGTGGGCGCGTGTTATGGGTG } \\
\text { ACGACTTTGTTATTTTCGACGGCGTATTTCATCGTAACTCTGATGGCCTGCTGGTTTGCGA } \\
\text { GCTGGAGCCGGCCTACACTAGCGACAACCTGCCTTTCCTGGGTTTCTACCATATGGCAAA } \\
\text { CGCGGCACTGAACCGTCTGCGTCAGCAAGCTAACCTGCGCGACTTCTACGACGTTATCG } \\
\text { TTGAGGAAGTGCGCCGCATGACGGGTTTCGACCGCGTCATGCTGTACCGTTTTGATGAA } \\
\text { AACAACCACGGTGACGTAATCGCGGAGGATAAGCGTGACGACATGGAGCCGTATCTGGG } \\
\text { TCTGCACTACCCGGAAAGCGACATTCCTCAGCCGGCACGTCGCCTGTTCATTCACAACCC } \\
\text { GATCCGTGTTATTCCGGACGTTTACGGCGTTGCTGTTCCGCTGACTCCGGCCGTTAATCC } \\
\text { GTCTACTAACCGTGCAGTTGACCTGACCGAATCCATCCTGCGTTCCGCATACCATTGCCA } \\
\text { CCTGACCTATCTGAAGAACATGGGCGTTGGTGCTAGCCTGACGATCTCTCTGATTAAAGA } \\
\text { TGGTCACCTGTGGGGTCTGATCGCTTGCCATCACCAGACCCCGAAAGTAATCCCTTTCGA } \\
\text { ACTGCGTAAAGCCTGCGAATTCTTCGGTCGTGTGGTGTTCTCTAATATCTCCGCGCAAGA } \\
\text { AGACACCGAGACTTTTGACTACCGCGTACAGCTGGCGGAGCATGAAGCGGTTCTGCTGG } \\
\text { ACAAAATGACCACCGCGGCAGACTTCGTGGAGGGCCTGACTAACCACCCAGACCGTCTG } \\
\text { CTGGGCCTGACCGGCAGCCAAGGCGCTGCGATTTGTTTCGGCGAGAAACTGATTCTGGT } \\
\text { GGGCGAAACCCCAGACGAAAAGGCGGTGCAATACCTGCTGCAATGGCTGGAGAATCGC } \\
\text { GAAGTGCAGGACGTTTTCTTCACTAGCTCTCTGTCTCAGATCTATCCGGATGCGGTTAAC } \\
\text { TTCAAAAGCGTGGCGTCCGGCCTGCTGGCTATCCCGATCGCCCGTCATAACTTTCTGCTG } \\
\text { TGGTTCCGCCCGGAGGTTCTGCAGACCGTTAATTGGGGTGTGATCCGAATCACGCATA } \\
\text { CGAAGCAACCCAAGAAGATGGTAAGATCGAACTGCATCCGCGTCAGTCCTTCGATCTGTG } \\
\text { GAAAGAATTGTTCGCCTGCAGAGCCTGCCGTGGCAGAGCGTTGAGATCCAGTCTGCCC } \\
\text { TGGCTCTGAAGAAAGCAATCGTGAACCTGATTCTGCGCCAAGCTGAAGAA }\end{array}$ \\
\hline A.t.-o & $\begin{array}{l}\text { CAGCGTGAACGTCTGGAGAAAGTCATGTCTTCTCATACTCCAAAACTGGACTCCTGTGGC } \\
\text { GCAGAACCGATTCACATCCCGGGCGCGATTCAGGAGCATGGTGCGCTGCTGGTACTGTC } \\
\text { CGCTCGCGAATTCTCTGTGGTTCAGGCTTCTGATAACCTGGCAAACTACATCGGTGTAGA } \\
\text { TCTGCCAATCGGTGCCGTTGCTACTGAAGCAAATCTGCCGTTCATTAGCGTGCTGTCCGC } \\
\text { ATGGTACTCTGGTGAAGAATCCAATTTCCGTTATGCATGGGCGGAAAAGAAACTGGACGT } \\
\text { GAGCGCTCATCGTAGCGGCACCCTGGTCATCCTGGAAGTGAAAAGGCTGGTGTGGGCG } \\
\text { AATCTGCGGAGAAACTGATGGGCGAATGACCTCCCTGGCAAAATATCTGAACTCCGCG } \\
\text { CCGTCCCTGGAAGACGCGCTGTTCCGTACCGCCCAACTGGTATCCAGCATTTCTGGTCAT } \\
\text { GACCGTACCCTGATCTATGATTTCGGTCTGGACTGGTCTGGCCATGTTGTTGCAGAAGCG } \\
\text { GGCTCCGGCGCTCTGCCGTCCTACCTGGGCCTGCGTTTCCCGGCAGGTGACATTCCGC } \\
\text { CGCAGGCACGTCAGCTGTATACCATCAACCGCCTGCGTATGATTCCAGACGTGGATTACA } \\
\text { AACCAGTGCCGATCCGCCCGGAAGTTAACGCTGAAACTGGCGCAGTGCTGGACATGAGC } \\
\text { TTCTCCCAGCTGCGTTCTGTTTCTCCGGTTCACCTGGAATATATGCGTAACATGGGTACT }\end{array}$ \\
\hline
\end{tabular}




\begin{tabular}{|l|l|}
\hline GCAGCAAGCATGTCCGTGTCCATTGTTGTTAACGGTGCCCTGTGGGGTCTGATCGCGTG \\
CTCAGCACGCTACCCCGCACTCTGTATCCCTGGCCGTTCGCGAAGCATGTGACTTCGCAG \\
GTGGAGCTGGGTCACATCCAGGCTCGCCTGCTGAAAGGCATGGCTGCAGCCGAGAAAT \\
GGGTCGATGGTCTGCTGGGTGGTAAGGCGAACGTGAAGATCTGCTGAAACAGGTTGGC \\
GCGGATGGCGCGGCCCTGGTCCTGGGCGACGACTACGAACTGGTTGGCAATACCCCGA \\
GCCGCGAACAGGTGGAAGAGCTGATTCTGTGGCTGGGCGAACGTGAGATCGCAGACGT \\
TTTCGCTACGGATAACCTGGCTGGTAACTACCCTACTGCTGCAGCGTATGCATCTGTGGC \\
CTCCGGTATCATCGCGATGCGCGTGAGCGAGCTGCACGGCTCCTGGCTGATTTGGTTC \\
GTCCGGAAGTTATCAAAACTGTGCGCTGGGGTGGTGACCCTCATAAAACCGTGCAGGAA \\
AGCGGCCGTATCCATCCGCGCAAATCTTTCGAAATTTGGAAAGAACAACTGCGTAACACT \\
AGCTTCCCGTGGTCTGAACCGGAGCTGGCGGCAGCCCGCGAACTGCGTGGCGCGATCA \\
TCGGCATCGTCCTGCGCAAAACTGAAGAA
\end{tabular}


Table S4. Protein sequences of red light activated RTKs

\begin{tabular}{|c|c|}
\hline Name & Sequence \\
\hline mFGFR1-CPH1S-o & $\begin{array}{l}\text { MGSSKSKPKDPSQRLDMKSGTKKSDFHSQMAVHKLAKSIPLRRQVTVSADSSASMNS } \\
\text { GVLLVRPSRLSSSGTPMLAGVSEYELPEDPRWELPRDRLVLGKPLGEGCFGQVVLAEAI } \\
\text { GLDKDKPNRVTKVAVKMLKSDATEKDLSDLISEMEMMKMIGKHKNIINLLGACTQDGPL } \\
\text { YVIVEYASKGNLREYLQARRPPGLEYCYNPSHNPEEQLSSKDLVSCAYQVARGMEYLA } \\
\text { SKKCIHRDLAARNVLVTEDNVMKIADFGLARDIHHIDYYKKTTNGRLPVKWMAPEALFDR } \\
\text { IYTHQSDVWSFGVLLWEIFTLGGSPYPGVPVEELFKLLKEGHRMDKPSNCTNELYMMM } \\
\text { RDCWHAVPSQRPTFKQLVEDLDRIVALTSNQEYLDLSIPLDQYSPSFPDTRSSTCSSGE } \\
\text { DSVFSHEPLPEEPCLPRHPTQLANSGLKRRVETGATTVQLSDQSLRQLETLAIHTAHLIQ } \\
\text { PHGLVVVLQEPDLTISQISANCTGILGRSPEDLLGRTLGEVFDSFQIDPIQSRLTAGQISSL } \\
\text { NPSKLWARVMGDDFVIFDGVFHRNSDGLLVCELEPAYTSDNLPFLGFYHMANAALNRL } \\
\text { RQQANLRDFYDVIVEEVRRMTGFDRVMLYRFDENNHGDVIAEDKRDDMEPYLGLHYPE } \\
\text { SDIPQPARRLFIHNPIRVIPDVYGVAVPLTPAVNPSTNRAVDLTESILRSAYHCHLTYLKN } \\
\text { MGVGASLTISLIKDGHLWGLIACHHQTPKVIPFELRKACEFFGRVVFSNISAQEDTETFDY } \\
\text { RVQLAEHEAVLLDKMTTAADFVEGLTNHPDRLLGLTGSQGAAICFGEKLILVGETPDEKA } \\
\text { VQYLLQWLENREVQDVFFTSSLSQIYPDAVNFKSVASGLLAIPIARHNFLLWFRPEVLQT } \\
\text { VNWGGDPNHAYEATQEDGKIELHPRQSFDLWKEIVRLQSLPWQSVEIQSALALKKAIVN } \\
\text { LILRQAEETGGSGVDYPYDVPDYALD }\end{array}$ \\
\hline rtrkB-CPH1S-o & $\begin{array}{l}\text { MGSSKSKPKDPSQRLDVTGKFGMKGPASVISNDDDSASPLHHISNGSNTPSSSEGGPD } \\
\text { AVIIGMTKIPVIENPQYFGITNSQLKPDTFVQHIKRHNIVLKRELGEGAFGKVFLAECYNLC } \\
\text { PEQDKILVAVKTLKDASDNARKDFHREAELLTNLQHEHIVKFYGVCVEGDPLIMVFEYMK } \\
\text { HGDLNKFLRAHGPDAVLMAEGNPPTELTQSQMLHIAQQIAAGMVYLASQHFVHRDLAT } \\
\text { RNCLVGENLLVKIGDFGMSRDVYSTDYYRVGGHTMLPIRWMPPESIMYRKFTTESDVW } \\
\text { SLGVVLWEIFTYGKQPWYQLSNNEVIECITQGRVLQRPRTCPQEVYELMLGCWQREPH } \\
\text { TRKNIKNIHTLLQNLAKASPVYLDILGTGGATTVQLSDQSLRQLETLAIHTAHLIQPHGLVV } \\
\text { VLQEPDLTISQISANCTGILGRSPEDLLGRTLGEVFDSFQIDPIQSRLTAGQISSLNPSKL } \\
\text { WARVMGDDFVIFDGVFHRNSDGLLVCELEPAYTSDNLPFLGFYHMANAALNRLRQQAN } \\
\text { LRDFYDVIVEEVRRMTGFDRVMLYRFDENNHGDVIAEDKRDDMEPYLGLHYPESDIPQP } \\
\text { ARRLFIHNPIRVIPDVYGVAVPLTPAVNPSTNRAVDLTESILRSAYHCHLTYLKNMGVGAS } \\
\text { LTISLIKDGHLWGLIACHHQTPKVIPFELRKACEFFGRVVFSNISAQEDTETFDYRVQLAE } \\
\text { HEAVLLDKMTTAADFVEGLTNHPDRLLGLTGSQGAAICFGEKLILVGETPDEKAVQYLLQ } \\
\text { WLENREVQDVFFTSSLSQIYPDAVNFKSVASGLLAIPIARHNFLLWFRPEVLQTVNWGG } \\
\text { DPNHAYEATQEDGKIELHPRQSFDLWKEIVRLQSLPWQSVEIQSALALKKAIVNLILRQA } \\
\text { EETGGSGVDYPYDVPDYALD }\end{array}$ \\
\hline
\end{tabular}


Table S5. DNA sequences of fluorescent transcriptional reporters

\begin{tabular}{|c|c|}
\hline SRE-mCherry & 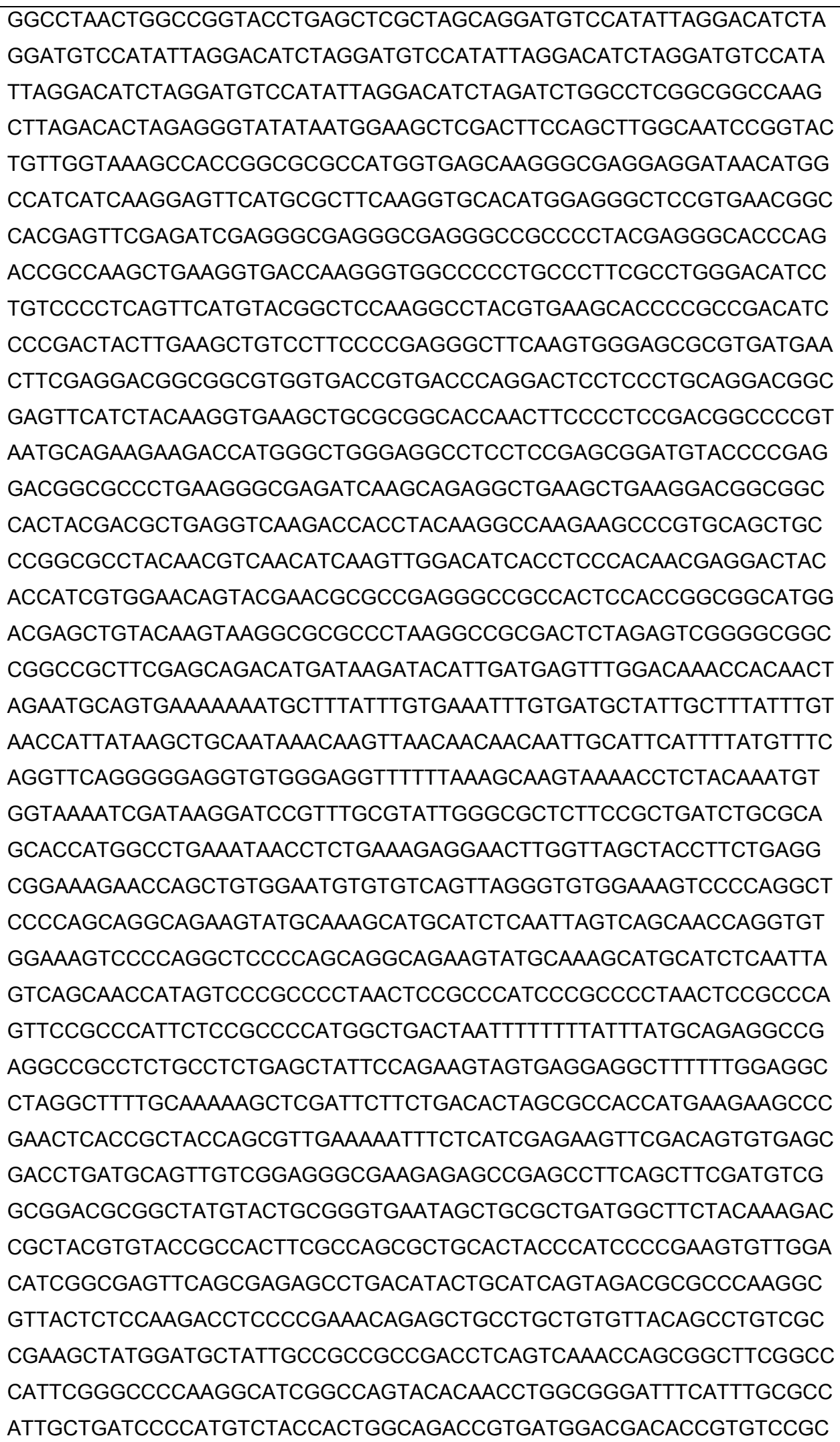 \\
\hline
\end{tabular}




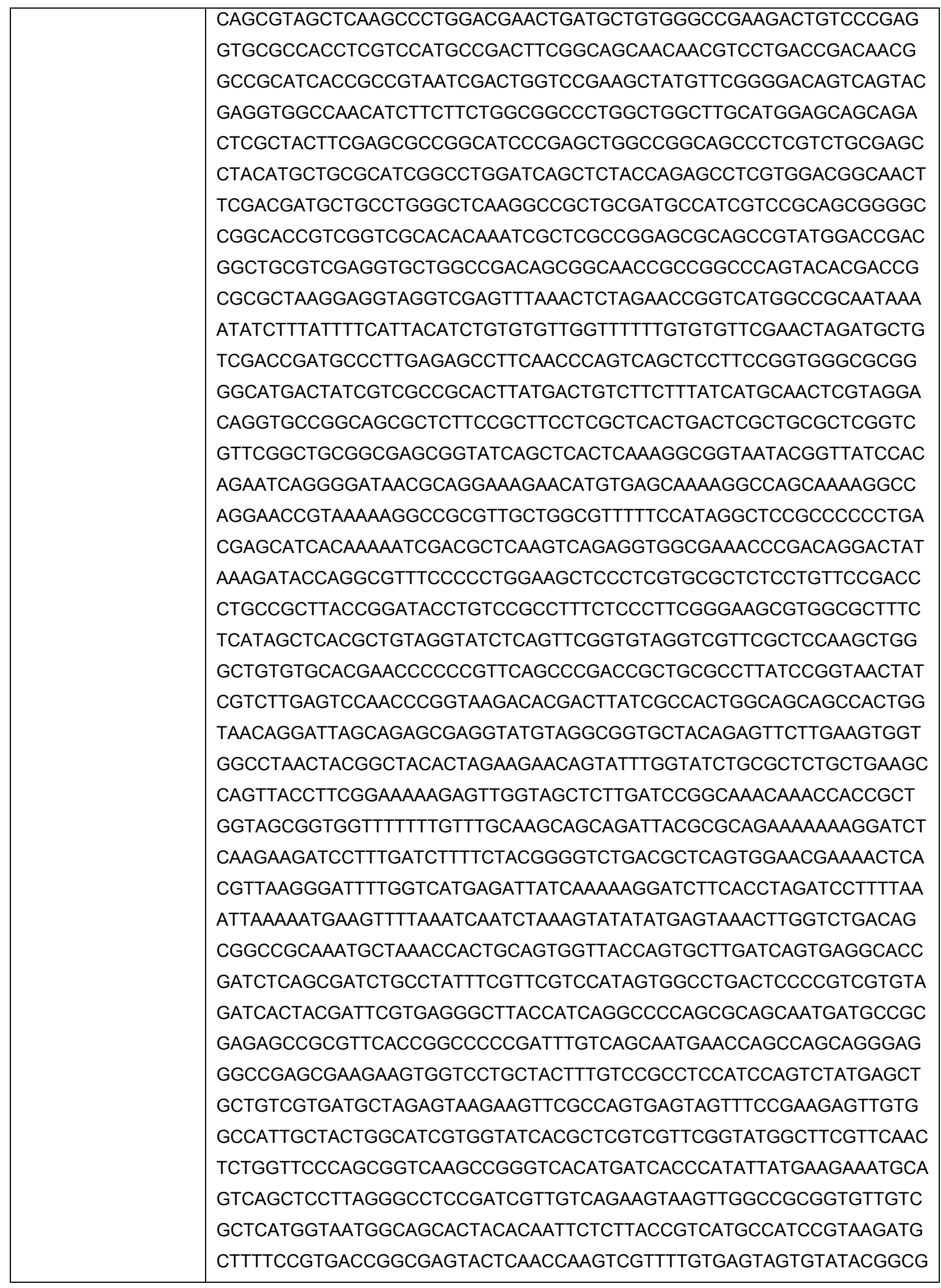




\begin{tabular}{|c|c|}
\hline & $\begin{array}{l}\text { ACCAAGCTGCTCTTGCCCGGCGTCTATACGGGACAACACCGCGCCACATAGCAGTA } \\
\text { CTTTGAAAGTGCTCATCATCGGGAATCGTTCTTCGGGGCGGAAAGACTCAAGGATC } \\
\text { TTGCCGCTATTGAGATCCAGTTCGATATAGCCCACTCTTGCACCCAGTTGATCTTCA } \\
\text { GCATCTTTTACTTTCACCAGCGTTTCGGGGTGTGCAAAAACAGGCAAGCAAAATGCC } \\
\text { GCAAAGAAGGGAATGAGTGCGACACGAAAATGTTGGATGCTCATACTCGTCCTTTTT } \\
\text { CAATATTATTGAAGCATTTATCAGGGTTACTAGTACGTCTCTCAAGGATAAGTAAGTA } \\
\text { ATATTAAGGTACGGGAGGTATTGGACAGGCCGCAATAAAATATCTTTATTTTCATTAC } \\
\text { ATCTGTGTGTTGGTTTTTTGTGTGAATCGATAGTACTAACATACGCTCTCCATCAAAA } \\
\text { CAAAACGAAACAAAACAAACTAGCAAAATAGGCTGTCCCCAGTGCAAGTGCAGGTG } \\
\text { CCAGAACATTTCTCT }\end{array}$ \\
\hline SRE-mCerulean3 & $\begin{array}{l}\text { GGCCTAACTGGCCGGTACCTGAGCTCGCTAGCAGGATGTCCATATTAGGACATCTA } \\
\text { GGATGTCCATATTAGGACATCTAGGATGTCCATATTAGGACATCTAGGATGTCCATA } \\
\text { TTAGGACATCTAGGATGTCCATATTAGGACATCTAGATCTGGCCTCGGCGGCCAAG } \\
\text { CTTAGACACTAGAGGGTATATAATGGAACTCGACTTCCAGCTTGGCAATCCGGTAC } \\
\text { TGTTGGTAAAGCCACCGGCGCGCATGGTGAGCAAGGGCAGGAGCTGTTCACCG } \\
\text { GGGTGGTGCCCATCCTGGTCGAGCTGGACGGCGACGTAAACGGCCACAAGTTCAG } \\
\text { CGTGTCCGGCGAGGGCGAGGGCGATCCACCTACGGCAAGCTGACCCTGAAGTTC } \\
\text { ATCTGCACCACCGGCAAGCTGCCCGTGCCCTGGCCCACCCTCGTGACCACCCTGA } \\
\text { GCTGGGGCGTGCAGTGCTTCGCCCGCTACCCCGACCACATGAAGCAGCACGACTT } \\
\text { CTTCAAGTCCGCCATGCCCGAAGGTACGTCCAGGAGCGCACCATCTTCTTCAAGG } \\
\text { ACGACGGCAACTACAAGACCCGCGCCGAGGTGAAGTTCGAGGGCGACACCCTGGT } \\
\text { GAACCGCATCGAGCTGAAGGGCATCGACTTCAAGGAGGACGGCAACATCCTGGGG } \\
\text { CACAAGCTGGAGTACAACGCCATCCACGGCAACGTCTATATCACCGCCGACAAGCA } \\
\text { GAAGAACGGCATCAAGGCCAACTTCGGCCTCAACTGCAACATCGAGGACGGCAGC } \\
\text { GTGCAGCTCGCCGACCACTACCAGCAGAACACCCCCATCGGCGACGGCCCCGTGC } \\
\text { TGCTGCCCGACAACCACTACCTGAGCACCCAGTCCAAGCTGAGCAAAGACCCCAAC } \\
\text { GAGAAGCGCGATCACATGGTCCTGCTGGAGTTCGTGACCGCCGCCGGGATCACTC } \\
\text { TCGGCATGGACGAGCTGTACAAGTAGGGCGCGCCCTAAGGCCGCGACTCTAGAGT } \\
\text { CGGGGCGGCCGGCCGCTTCGAGCAGACATGATAAGATACATTGATGAGTTTGGACA } \\
\text { AACCACAACTAGAATGCAGTGAAAAAATGCTTTATTTGTAAATTTGTGATGCTATT } \\
\text { GCTTTATTTGTAACCATTATAAGCTGCAATAAACAAGTTAACAACAACAATTGCATTC } \\
\text { ATTTTATGTTTCAGGTTCAGGGGGAGGGTGGGAGGTTTTTAAAGCAAGTAAAACC } \\
\text { TCTACAAATGTGGTAAAATCGATAAGGATCCGTTTGCGTATTGGGCGCTCTTCCGCT } \\
\text { GATCTGCGCAGCACCATGGCCTGAATAACCTCTGAAAAGGAATTGGTTAGCTA } \\
\text { CCTTCTGAGGCGGAAAGACCAGCTGTGGAATGGTGCAGTTAGGGTGTGAAAG } \\
\text { CATCTCAATTAGTCAGCAACCATAGTCCCGCCCCTAACTCCGCCCATCCCGCCCCTA } \\
\text { ACTCCGCCCAGTTCCGCCCATTCTCCGCCCCATGGCTGACTAATTTTTTTTATTTATG } \\
\text { CAGAGGCCGAGGCCGCCTCTGCCTCTGAGCTATTCCAGAAGTAGTGAGGAGGCTTT } \\
\text { TTTGGAGGCCTAGGCTTTTGCAAAAAGCTCGATTCTTCTGACACTAGCGCCACCATG }\end{array}$ \\
\hline
\end{tabular}




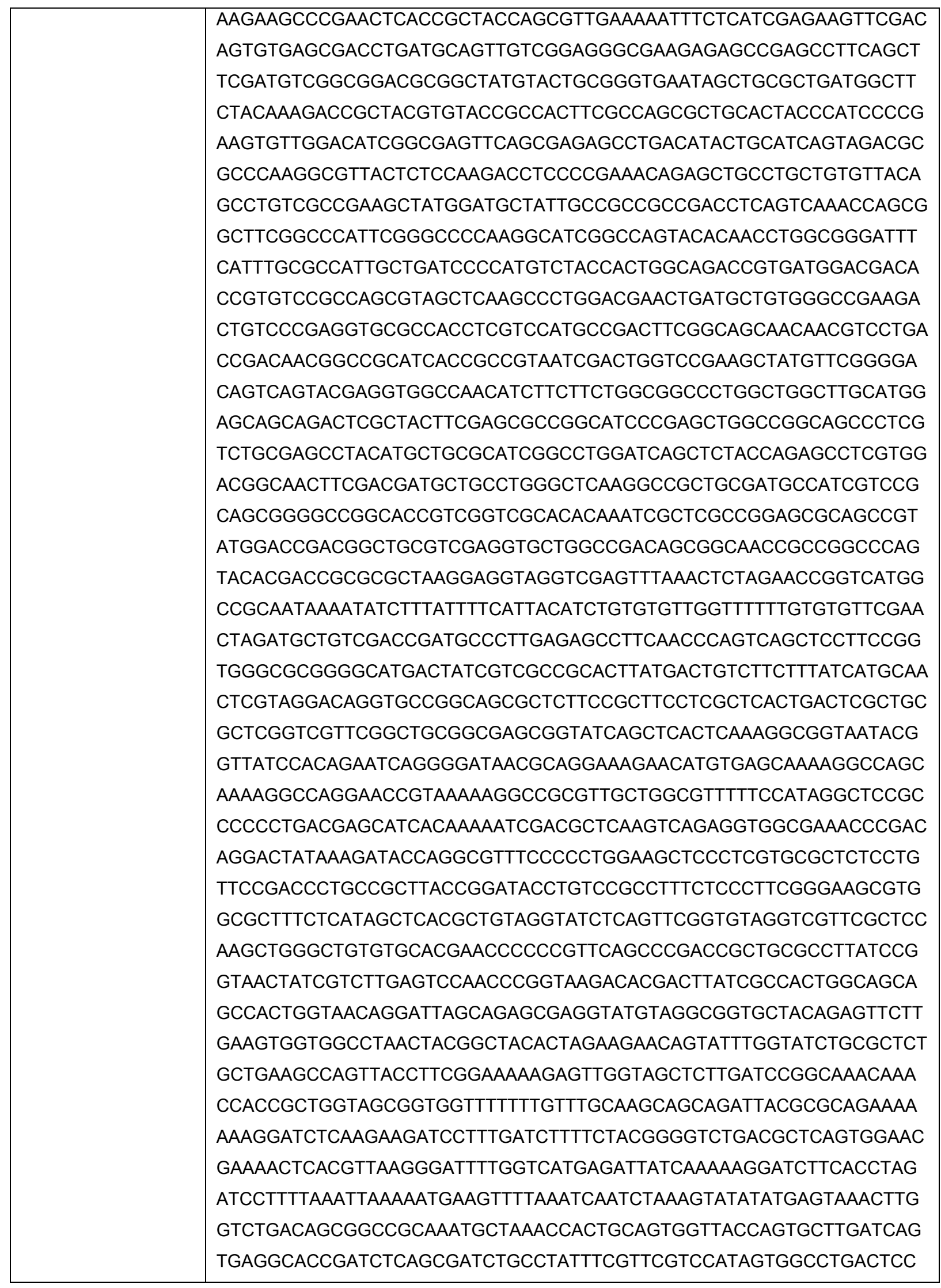




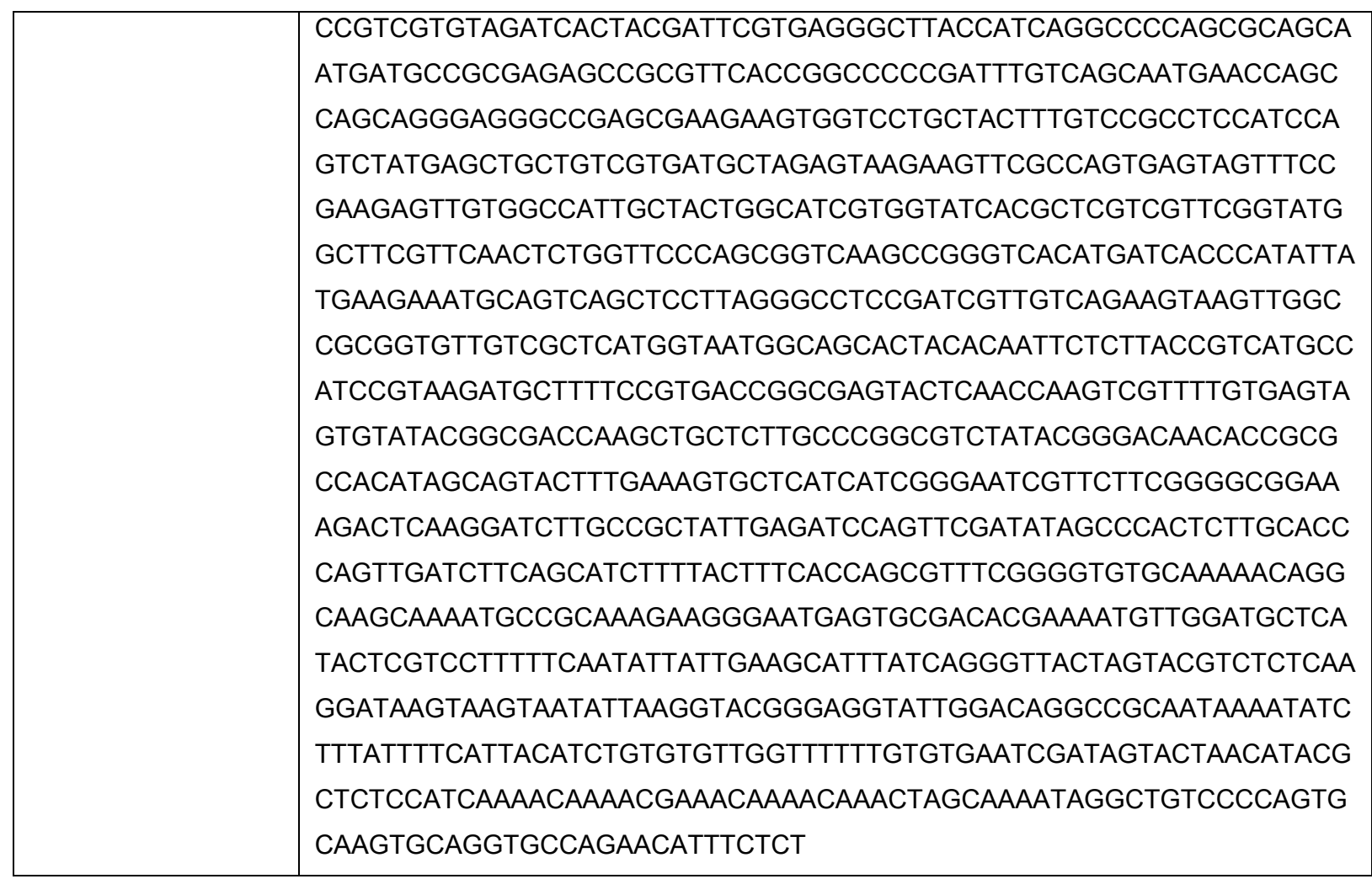




\section{References}

[1] M. Grusch, K. Schelch, R. Riedler, E. Reichhart, C. Differ, W. Berger, A. Ingles-Prieto, H. Janovjak, EMBO J. 2014, 33, 1713-1726.

[2] N. Watanabe, T. J. Mitchison, Science 2002, 295, 1083-1086.

[3] A. Merglen, S. Theander, B. Rubi, G. Chaffard, C. B. Wollheim, P. Maechler, Endocrinology 2004, 145, 667678.

[4] T. Nagai, K. Ibata, E. S. Park, M. Kubota, K. Mikoshiba, A. Miyawaki, Nat. Biotechnol. 2002, 20, 87-90.

[5] a) A. N. Yaroslavsky, V. Neel, R. R. Anderson, J. Invest. Dermatol. 2003, 121, 259-266; b) S. Wan, J. A.

Parrish, R. R. Anderson, M. Madden, Photochem. Photobiol. 1981, 34, 679-681; c) G. Marquez, L. V. Wang, S. P. Lin, J. A. Schwartz, S. L. Thomsen, Appl. Opt. 1998, 37, 798-804. 